\title{
REAL WAGES, INEQUALITY AND GLOBALIZATION IN LATIN AMERICA BEFORE 1940
}

\author{
JEFFREY G. WILLIAMSON \\ Harvard University
}

\section{RESUMEN}

Hacia 1914 existían notables diferencias económicas entre los países del Cono Sur y Cuba y el resto de América Latina. El artículo indaga las razones de estas diferencias, cuando aparecieron, así como la distancia existente entre los países latinoamericanos, los de la cuenca mediterránea y el líder industrial. Se ocupa de examinar el papel que desempeñaron las fuerzas demográficas, la localización geográfica y el grado de globalización e integracion económica. El trabajo utiliza nuevos datos de salarios reales y precios relativos de los factores de siete países latinoamericanos y de tres regiones mediterráneas. Estos datos se comparan con la información disponible para Gran Bretaña y los Estados Unidos.

\section{ABSTRACT}

By 1914, there were huge economic gaps between the Southern Cone plus Cuba and the rest of Latin America. Can they be explained by the varying ability of these countries to exploit the first great globalization boom after about 1870? Or did the gaps appear much earlier? And what about the gaps between Latin America and the Mediterranean, let alone with industrial leaders like Britain? What role did geographic isolation, globalization and demographic forces play in the process? Conventional GDP estimates are much too coarse to confront these questions. This essay uses a new data base on real wages and relative factor prices for seven Latin American and three Mediterranean regions, the latter being a source of so many of immigrants for the former. These ten regions, plus comparative information from Britain and the United States, form the data base for the paper. 


\section{NEW DATA, OLD QUESTIONS}

Two important features of the world economy after 1950 also characterized it before 1914. First, there was rapid globalization a century ago too: capital and labor flowed across national frontiers in unprecedented quantities, and at rising rates; and commodity trade boomed as transport costs dropped sharply. Second, the late 19th century underwent an impressive convergence in living standards, at least within most of what we would now call the OECD club, but what historians call the Atlantic economy. Poor countries around the European periphery tended to grow faster than the rich industrial leaders at the European core, and often even faster than the richer countries overseas in the New World. This club excluded most of what is now called the Third World and eastern Europe, and even around this limited periphery there were some who failed to catch up. Nonetheless, there was convergence.

It was not always that way: unambiguous divergence took place earlier. In the first half of the previous century, the Atlantic economy was characterized by high tariffs, modest commodity trade, no mass migrations, and an underdeveloped global capital market. Two profound shocks occurred in this environment still hostile to liberal globalization policy: early industrialization in Britain which then spread to a few countries on the European continent; and resource «discovery» in the New World, set in motion by sharply declining transport costs linking overseas suppliers to European markets, so much so that real freight rates fell by an enormous 1.5 percent per annum between 1840 and 1910 (O'Rourke and Williamson 1998). These two shocks triggered a divergence in real wages and living standards across the Atlantic economy that lasted until the middle of the century (Williamson 1996) ${ }^{1}$.

Figure 1 shows that the Atlantic economy convergence which started in mid-century continued up to 1914: a plot of the dispersion of real wages is given there, documenting what the modern macro economists call sigma-convergence. The line with the diamonds on the upper left of Figure 1 is based on a 13 -country Atlantic economy sample including Australia,

${ }^{1}$ Prasannan Parthasarathi (1998) also uses this dating to describe lagging India, and so does Kenneth Pomeranz (1997) for lagging China. In contrast, Robert Allen (1998) argues that the divergence within Europe started long before the industrial revolution. Elsewhere, I explore these competing views with real wage evidence from the Mediterranean (Williamson 1998b; 1999b forthcoming) and Asia (Williamson 1998a; 1999a forthcoming), data much like that presented here for Latin America. 


\section{FIGURE 1}

International Real Wage Dispersion: The Atlantic Economy 1854-1913

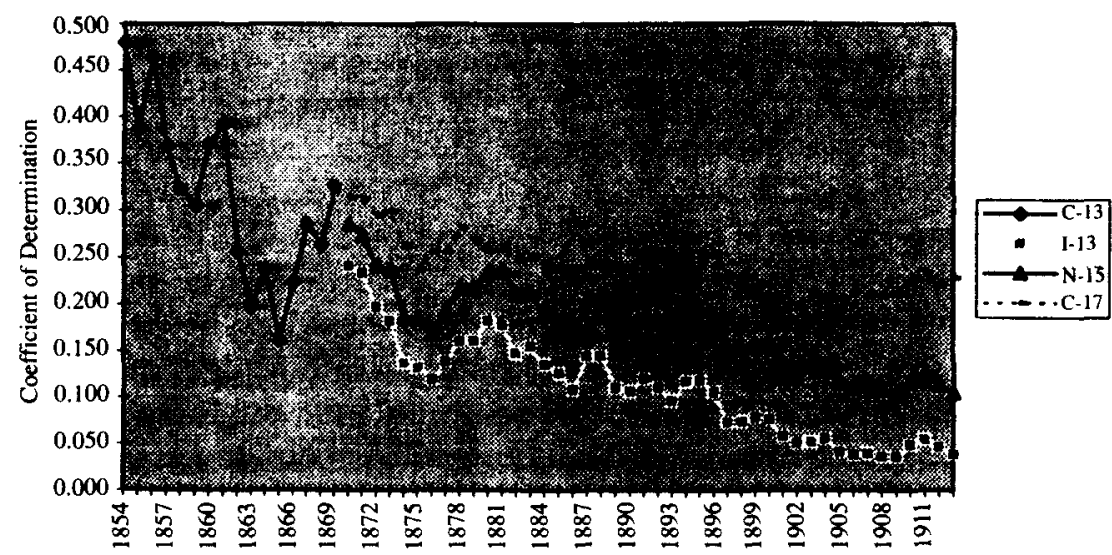

SOURCE: Williamson (1995, Table A2.1; revised in O'Rourke and Williamson, 1997).

Belgium, Brazil, France, Germany, Great Britain, Ireland, the Netherlands, Norway, Portugal, Spain, Sweden and the United States. The dashed line in Figure 1 documents convergence for an expanded 17-country Atlantic economy sample, now including in addition Argentina, Canada, Denmark and Italy. This measure shows the convergence tide ebbing around 1900. If we exclude Canada and the United States, two «exceptional» rich countries which bucked the convergence tide, convergence continues rapidly up to 1914 (the 15-country sample plotted with the triangles). If we exclude in addition two Mediterranean Basin countries which failed to play the globalization game, Portugal and Spain, convergence up to 1914 is faster still (the 13-country sample plotted with the squares).

Meanwhile, how did Latin America do? Based on macro data reviewed by John Coatsworth (1993), it is very difficult to tell. Coatsworth thinks that there was no growth in GDP per capita at all in any of the colonial economies between 1700 and 1820 . Since there was hardly much per capita income growth in Europe either during that century, one might conclude that Latin America maintained its relative position vis a vis Europe, and that the economic gaps between regions within Latin America changed but little. The half century between 1820 and 1870 was one of revolution, civil war and early independence. Like Africa today, Latin America was 
an economic and political basket case. Angus Maddison (1995) offers GDP per capita growth evidence for Brazil and Mexico only, and they both do very badly, Brazil growing by only 10 percent over the five decades as a whole and Mexico declining by 7 percent. Coatsworth guesses that Colombia underwent no growth over the period. This evidence certainly confirms that Latin America must have lost a lot in the race with the United States and Britain, since those two leaders registered GDP per capita growth rates of about 1 percent per annum up to 1870 . The evidence says very little, however, about growing or contracting gaps between regions within Latin America. Latin American economic performance is better documented between mid-century and the Great War in Europe (Maddison 1995; Engerman and Sokoloff 1996), and the period offers two notable facts. First, the poorest Latin American countries were growing slowest, illustrated by Brazil and Peru, while the richest Latin American countries were growing fastest, illustrated by Argentina, Chile and Mexico. This limited evidence certainly seems to point to economic divergence within the region. Second, the region as a whole seemed to be holding its own relative to Europe. Indeed, the fast growing richer regions were actually catching up. We would like to be more precise, however. Exactly when and where did the catching up and falling behind take place? We need to know the answers if the correlates of economic success and failure in Latin America are to be identified. This macro data just reviewed will not provide the necessary evidence since it is available only for benchmark years separated by decades, and important regions like Cuba and Colombia are excluded.

In any case, and as I shall stress below, GDP per capita and real wages would have grown at the same rate only under unusual conditions, conditions that were very unlikely to have been satisfied prior to 1940 . So, what happened to real wages and living standards when Latin America responded to the challenge of both the European Industrial Revolution and the first great globalization boom? And what happened to both real wages and GDP per capita during war, interwar and autarky after 1913 when external economic policy underwent such spectacular change?

These are the questions that motivate this essay. They are in the tradition of W. Arthur Lewis who was the first to ask whether the core pulled along the periphery during this first great globalization boom (Lewis 1969, 1978a, 1978b). It was he, together with Alexander Gerschenkron (1952), who first tried to break the economic historian's tenacious fixation on the industrial leaders, Lewis focusing on the Third World and Gerschenkron on European late comers like Italy and eastern Europe. Thus, these ques- 
tions are not new to Latin American economic history, but they could not be attacked very well even only a decade ago since the data had not been gathered in such a way as to make these comparative judgments possible. Now we have enough to make some real progress.

\section{OVERTHROWING THE TYRANNY OF DISTANCE IN LATIN AMERICA AND THE GREAT TERMS OF TRADE DEBATE}

In a book entitled The Tyranny of Distance, Geoffrey Blainey showed how distance shaped Australian history. Distance had the same impact on the rest of Asia until late in the 19th century, isolating Asia from Europe where, after all, the industrial revolution was unfolding. Late in the 19th century, transport innovations started to change all that, although not completely. The appearance of the Suez Canal, cost-reducing innovations on sea-going transport, and railroads penetrating the interior may not have completely liberated Asia from the tyranny of distance by 1914, but it certainly helped enormously.

Why shouldn't this account about economic isolation apply to Latin America as well? It is certainly consistent with the «new economic geography» (Krugman 1991a, 1991b). After all, the economic distance to the European core varied considerably depending on location in Latin America. The Panama Canal was not completed until 1914, and before then the Andean economies - Peru and Ecuador- must have been very seriously disadvantaged in European trade. And prior to the introduction of a railroad network, which didn't really start until the 1870 s, the landlocked countries of Bolivia and Paraguay were at an even more serious disadvantage. This was also true of the Mexican interior (Coatsworth 1981), the Colombian interior, and the Argentine interior (Newland 1998). A close observer of early 19th century Latin America, Belford Hinton Wilson, reported in 1842 the cost of moving a ton of goods from England to the following capital cities (in pounds sterling): Buenos Aires and Montevideo 2; Lima 5.12; Santiago 6.58; Caracas 7.76; Mexico City 17.9; Quito 21.3; Sucre or Chuquisca, 25.56; and Bogota 52.9. The variance is huge, with the costs to Equador (Quito), Bolivia (Sucre or Chuquisca), New Granada (e.g., Colombia, Bogota), and Mexico nine to twenty-seven times that of Buenos Aires and Montevideo, both well placed on either side of the Rio de la Plata (Brading 1969). 
Geographic isolation helps explain much of the economic ranking of nations in 1870, with poor countries most isolated: Argentina and Uruguay at the top; Cuba and Mexico next; Columbia and southeast Brazil third; and Peru, Ecuador, Bolivia and Paraguay at the bottom. Of course, there were other factors at work like slavery and bad luck in world commodity markets (e.g, the Brazilian Northeast). Furthermore, geographic isolation helps explain much of the subsequent poor growth performance in these mostly poor parts of Latin America after 1870. Even after the late 19th century railroad boom, much of the Latin American interior was still isolated: for example, railway track per 1,000 population in Bolivia, Ecuador, Paraguay and Peru was still only about a tenth that of Australia, New Zealand and Canada in 1912 (Bulmer-Thomas 1994). Furthermore, the tyranny of distance did not disappear as a development obstacle in these poor and initially-isolated parts of Latin America even after 1950. Indeed, economists have shown that poor growth performance today is still associated with whether a country is landlocked, whether the length of its coastline is limited, and whether its distance from Tokyo, New York or Rotterdam is long (Radelet, Sachs and Lee 1997). Bolivia, Ecuador, Paraguay, Peru, the Argentine interior and the Mexican interior all face a trade disadvantage, and if trade matters to growth, those regions face a growth disadvantage as well.

In contrast, the Latin American regions bordering on the Atlantic, with long coastlines and with good navigable river systems, have always been favored by a trade advantage and thus a growth advantage as well. These include Argentina, Brazil, Venezuela, Central America, Cuba and the other Caribbean islands. Of course, these regions may have failed for other reasons, but geographic isolation certainly wasn't one of them.

Transport cost declines from interior to port, and from port to Europe or to the East and Gulf Coast of the United States, ensured that Latin American economies became more integrated into world markets after around 1850. Price gaps between Britain and both Americas were driven down and trade stimulated as a consequence. True, transport costs and price differentials involving trade between Europe and North America are far better documented than are those between Europe and South America. Yet, the qualitative literature suggests that the same was happening south of the US border.

Prior to the railway era, transportation was either by road or water, with water being the cheaper option by far. Thus, investment in river and harbor improvements increased briskly everywhere in the Atlantic economy. 
Steamships were the most important 19th century contribution to shipping technology. The Claremont made its debut on the Hudson in 1807; a steamer had made the journey up the Mississippi as far as Louisville by 1815; British steamers had traveled up the Seine to Paris by 1816. In the first half of the century, steamships were mainly used on important rivers, the Great Lakes, and inland seas such as the Baltic and the Mediterranean. A regular trans-Atlantic steam service was inaugurated in 1838 , but until 1860 steamers mainly carried high-value goods similar to those carried by airplanes today, like passengers, mail and gourmet food.

The switch from sail to steam may have been gradual, but it accounted for a steady decline in transport costs across the Atlantic (Harley 1988). A series of innovations in subsequent decades helped make steamships more efficient: the screw propeller, the compound engine, steel hulls, bigger size and shorter turn-around time in port. Before 1869 , steam tonnage had never exceeded sail tonnage in British shipyards; in 1870, steam tonnage was over twice as great as sail, and sail tonnage only exceeded steam in two years after that date (Fletcher 1958).

Refrigeration was another technological innovation with major trade implications. Mechanical refrigeration was developed between 1834 and 1861 , and by 1870 chilled beef was being transported from the United States to Europe (Mokyr 1990). In 1876, the first refrigerated ship, the Frigorifique, sailed from Argentina to France carrying frozen beef. By the 1880 s, South American meat was being exported in large quantities to Europe. Not only did railways and steamships mean that European farmers were faced with overseas competition in the grain market, but refrigeration also deprived them of the natural protection distance had always provided local meat and dairy producers. The consequences for European farmers of this overseas competition would be profound (O'Rourke 1997; O'Rourke and Williamson 1999).

What was the impact of these transport innovations on the cost of moving goods between markets? Certainly trade boomed in Latin America. While the estimates offered by Victor Bulmer-Thomas (1994) may be rough, they certainly prove the point. The share of Latin American exports in GDP was around 10 percent in 1850, while in 1912 it was 25 percent. But when economists look at this period, they tend to ignore the fact that the decline in transatlantic transport costs after mid century was enormous, and focus instead only on trade. This is a mistake. The volume of trade is not by itself a satisfactory index of commodity market integration. It is the cost of moving goods between markets that counts. The cost 
has two parts, that due to transport and that due to trade barriers (such as tariffs). The price spread between markets is driven by changes in these costs, and they need not move in the same direction. It turns out that tariffs in the Atlantic economy did not fall from the 1870s to World War I; the globalization which took place in the late 19th century cannot be assigned to more liberal trade policy. Instead, it was falling transport costs which provoked globalization. Indeed, rising tariffs were mainly a defensive response to the competitive winds of market integration as transport costs declined (O'Rourke and Williamson 1998).

This is an important point that somehow has disappeared from the collective memory of the economics profession: while the late $19^{\text {th }}$ century Atlantic economy was certainly more «liberal» than between 1914 and 1950, it was also a period of retreat from openness. Yet, the decline in international transport costs overwhelmed the retreat from free trade, thus implying commodity price convergence between center and periphery. The impact of these productivity improvements on transport costs around the Atlantic economy can be seen graphically in Figure 2. What is labeled the North index (North 1958) accelerates its fall after the 1830s, and what is labeled the British index (Harley 1988) is fairly stable up to mid century before undergoing the same, big fall. The North freight rate index among American export routes dropped by more than 41 percent in real terms between 1870 and 1910. The British index fell by about 70 percent, again in real terms, between 1840 and 1910 . These two indices imply a steady decline in Atlantic economy transport costs of about 1.5 percent per annum, for a total of 45 percentage points up to 1913 , a big number indeed. There is another way to get a comparative feel for the magnitude of this decline. The World Bank reports that tariffs on manufactures entering developed country markets fell from 40 percent in the late 1940 s to 7 percent in the late 1970s, a 33 percentage point decline over thirty years (Wood 1994). While impressive, this spectacular postwar reclamation of «free trade» from interwar autarky is still smaller than the 45 percentage point fall in trade barriers between 1870 and 1913 due to transport improvements.

Declining transport costs produced profound commodity price convergence between Latin America and Europe, at least if they behaved anything like Anglo-American price differentials. Liverpool wheat prices exceeded Chicago wheat prices by 58 percent in 1870 , by 18 percent in 1895 , and by 16 percent in $1912^{2}$. Moreover, these estimates understate the size

${ }^{2}$ The remainder of this paragraph draws its evidence from O'Rourke and Williamson (1994). 


\section{FIGURE 2}

Atlantic Economy Ocean Freight Rate Indices 1741-1913

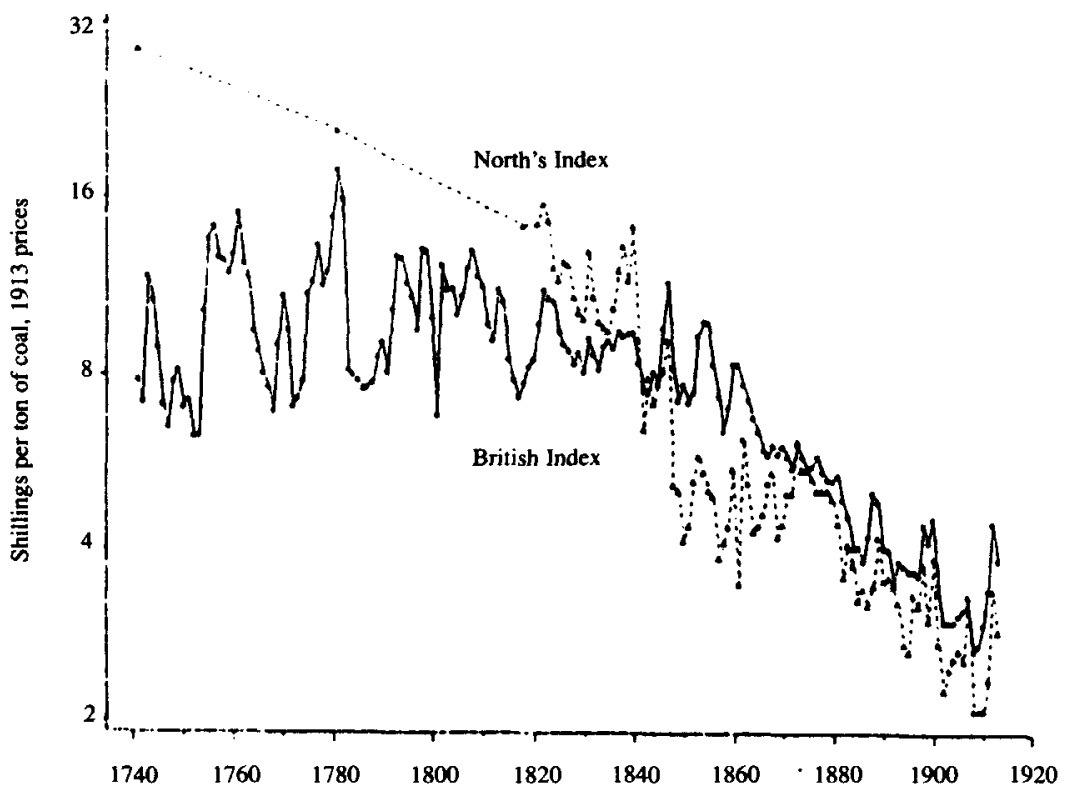

SouRCE: Harley (1988, Figure 1), deflated by UK GNP deflator, ratio scale.

of the price convergence because they ignore the collapse in price gaps between farm and interior railhead. Was the experience in Anglo-American wheat markets repeated for other foodstuffs? The second biggest tradable foodstuff consisted of meat and animal fats such as beef, pork, mutton and butter. Based on London-Cincinnati price differentials for bacon, there was no convergence across the 1870 s and 1880 s, but the price convergence after 1895 was even more dramatic for meat than it was for wheat: price gaps were 93 percent in 1870,92 percent in 1895 , and 18 percent in 1913. The delay in price convergence for meat has an easy explanation: it required the advances in refrigeration made towards the end of the century. Anglo-American price data are also available for many other non-agricultural commodities. The Boston-Manchester cotton textile price gap, which had been 14 percent in 1870 , completely vanished by 1913; the Philadelphia-London iron bar price gap fell from 75 to 21 percent, while the pig iron price gap fell from 85 to 19 percent, and the copper price 
gap fell from 33 percent to almost zero. More relevant to Argentina and Uruguay, the Boston-London hides price gap fell from 28 to 9 percent, while the wool price gap fell from 59 to 28 percent.

The decline in transport costs created commodity price convergence in the Atlantic economy up to the Great War, and most of Latin America was part of it. Trade boomed. Of course, we would like to know more about where the commodity price convergence forces were greatest. Did the tyranny of distance suffer a bigger defeat in the more isolated parts of Latin America or the less isolated parts? Did the poorer regions gain less than the richer ones? Furthermore, note that this stress on the decline in transportation costs between center and periphery ties in closely to a very important but historically very badly informed debate over the relative price of primary products. The so-called «terms of trade debate» has its origin in the collapse of primary product prices during the great depression, but Gunnar Myrdal, Ragnar Nurkse, Raul Prebisch and Hans Singer argued in the 1950s and 1960s that the downward trend was secular (Diakosavvas and Scandizzo 1991: 238-239). This interpretation served to fuel the policy move towards Third World autarky in the 1950s and 1960s. However, what these four intellectual giants failed to appreciate is that during transport revolutions - like that from the mid-19th century to World War Ithe terms of trade can (and did) rise for both center and periphery (Ellsworth 1956; Bairoch 1975). It was not a zero-sum game. With Latin American globalization forces now on the table, let us turn now to growth in the region.

\section{THE GROWTH OF WHAT?}

Most economists who have written about the comparative growth of nations have used GDP per capita or per worker to measure catching up and convergence, or falling behind and divergence. This and other essays of mine favor instead real wage rates (purchasing-power-parity adjusted, and typically for urban unskilled workers) and other factor prices (like land rents and skill premia). I can think of at least four good reasons why it is a mistake for the convergence debate to have ignored wages and other factor prices, especially for the previous century and earlier.

First, the pre-1940 real wage data - certainly for Latin America- are of far better quality than the GDP per capita data, and they are certainly available for a wider sample. Indeed, Angus Maddison (1995) is able to 
document real GDP per capita for a surprisingly small part of 19 th century Latin America: for 1820, he gives estimates of GDP per capita only for Brazil and Mexico, two countries which based on 1900 population weights would have accounted for only 53 percent of Latin America; a half century later, he offers estimates for one more, Argentina, raising the share of Latin America covered to 61 percent (again, based on 1900 population); thirty years later, he offers estimates for four more, but there are still many missing. It seems to me that the available GDP per capita data are not sufficient by themselves to deal adequately with the questions raised thus far in this essay. As the background paper for this essay shows (Williamson 1998c), real wages can be documented for the following (so far): Argentina from 1864; Southeast Brazil from 1830; Northeast Brazil from 1855; Colombia from 1863; Cuba from 1905; Mexico from 1877; and Uruguay from 1870 (augmented by Bertola et al. 1999). Furthermore, we can begin making statements about purchasing-power-parity (PPP) adjusted real wages relative to the European core from each of those dates. In addition, these real wage time series are typically available annually, so that epochs and major turning points can be identified with much greater clarity than is true of the GDP data which are typically reported for every two decades or even longer.

Second, income distribution matters, and wage rates (especially when combined with other factor prices) offer a window through which to look in on distribution issues. Real people earn wages or skill premia or profits or rents, not that statistical artifact known as GDP per capita. GDP per worker hour may sound like a good measure of aggregate productivity, but surely the living standards of ordinary workers as captured by real wages are a better indicator of the economic well-being of the vast majority in any society. By averaging all incomes, macro economists (and economic historians that mimic them) throw away valuable information.

Third, factor price movements help us understand the growth of nations. For example, productivity catch-up in Latin America was more likely to increase all factor prices equally than was mass immigration (increasing population pressure on the land) or an export boom for agricultural products (increasing the demand for immobile land more than mobile labor). The open economy forces which may have been important in driving late 19th century economic change in Latin America - trade, migration and capital flows- operated directly on factor prices, and thus only indirectly on GDP per capita ${ }^{3}$. An exclusive focus on GDP per capita misses most of the story.

\footnotetext{
${ }^{3}$ For a summary, see Williamson (1996) and O'Rourke and Williamson (1999).
} 
Fourth, economic change nearly always involves winners and losers, a fact which is crucial in accounting for the evolution of policy, perhaps more so in politically independent Latin American societies than in dependent colonial societies in Asia and Africa. Indeed, distributional effects may even influence the survival of newly independent countries. Changes that would increase GDP per capita but would also cause losses to some politically powerful group are often successfully resisted, and examining the behavior of factor prices is a good way to start the search for the sources of such political resistance.

\section{THE LATIN AMERICAN REAL WAGE HIERARCHY AROUND THE TURN OF THE CENTURY}

Table 1 pulls together estimates of the real wage hierarchy around Latin America and between it and the European industrial leader, Britain. The assessment is made around the turn of the century. All of the estimates in Table 1 calculate urban unskilled wages from various parts of Latin America relative to urban unskilled wages in Britain ${ }^{4}$. More importantly, none of the wage relatives in Table 1 are calculated at the prevailing exchange rate. It is well-known that the use of exchange rates, dominated by tradable goods, is inferior to the use of purchasing-power-parity, the latter constructed from workers' market baskets. However, trying to construct PPP-adjusted real wages based on common market baskets and region-specific relative prices would entail another research project. Table 1 uses a shortcut: we take the 1910 PPP-adjusted GDP per capita estimates reported recently by Pablo Astorga and Valpy FitzGerald (1998) as our benchmark and project our real wage series forward and backward from that point. To make the comparison with Britain, I use the $1910 \mathrm{PPP}$-adjusted urban unskilled real wages in Argentina and Britain reported in my previous work (Williamson 1995), and then adjust the remaining Latin American countries accordingly, a procedure which assumes that the cardinal ranking

${ }^{4}$ True, one of these regions, Northeast Brazil (Pernambuco), reports farm wages, not urban unskilled wages. But even in this case, if the wage gap between city and countryside was relatively stable over time then the Northeast Brazil time series would be an adequate proxy for changes in the real wages of urban workers. I have not been able to find the evidence for the Brazilian Northeast to confirm or deny this assumption. 


\section{TABLE 1}

The Latin American Real Wage Hierarchy Near the Turn of the Century

\begin{tabular}{|c|c|c|c|}
\hline \multirow[t]{2}{*}{ Region } & \multicolumn{3}{|c|}{$\begin{array}{c}\text { Real Wage Relative to Great Britain } \\
\text { (in percent) }\end{array}$} \\
\hline & $1873-1883$ & $1899-1903$ & $1909-1913$ \\
\hline Argentina & 74.2 & 100.9 & 97.9 \\
\hline 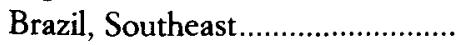 & 18.8 & 18.3 & 22.0 \\
\hline 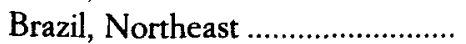 & 5.2 & 5.0 & 7.7 \\
\hline 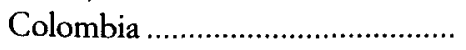 & 17.3 & $26.2^{* * *}$ & 24.5 \\
\hline Cuba & & & 73.9 \\
\hline 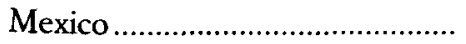 & $67.3^{*}$ & 58.2 & 65.3 \\
\hline Uruguay & $97.0^{* *}$ & 82.0 & 97.4 \\
\hline
\end{tabular}

SOURCES AND NOTES: The Latin American data are from Williamson (1998c), Appendix Tables 1-6, PPP-adjusted with Great Britain in 1913 =100. The British data is taken from my revised Atlantic economy data base (Williamson 1995; revised in O'Rourke and Williamson 1997).

* As the Mexico real wage series starts only in 1877 , this entry reports an average for 1877-1883.

** As the Uruguay real wage series starts only in 1880 , this entry reports an average for 1880-1883.

$\star * *$ As the Colombia real wage series excludes the years 1901-1908 because of hyperinflation in the country, this entry reports an average for 1899-1900.

of the Latin American countries relative to Argentina would be the same in 1910 for real unskilled urban wages and GDP per capita ${ }^{5}$.

The Latin American real wage hierarchy around the turn of century is clear enough, and while some of the estimates in Table 1 seem to be consistent with other qualitative and quantitative accounts, some are quite surprising.

The Brazilian Northeast was at the bottom of the hierarchy, with workers' living standards only 5-8 percent of those in Britain. Conditions were dismal in this region which had only recently freed these workers from slavery and which had been beset with sagging prices of their key expor-tables (Leff 1972), but it is hard to imagine living standards being much worse. Perhaps they are understated. While the Brazilian Northeast and

5 These PPP-adjustments are being revised, based on new research for both Argentina and Uruguay by Luis Bértola. These adjustments - as well as new time series for Mexico and Uruguay - will be used to make further revisions in the data base used in this essay. 
the Italian Mezzogiorno have always been cited as classic examples of regional «dualism» (Williamson 1965), wages in Brazil's poor Northeast were well below Italy's poor Mezzogiorno just prior to World War I, the former less than a third of the latter (Williamson 1998b). Even unskilled construction workers in Egypt had real wages almost double those in Northeast Brazil. Furthermore, none of the unskilled workers in Asian cities and towns had real wages that low: they were more than double that in Burma and India (Williamson 1998a). All of this suggests, incidentally, that the living standard gaps between regions in Latin America around World War I were far bigger than they were in either the Mediterranean or Asia.

Argentina and Uruguay were, of course, at the top of the heap, frequently switching the leadership position between the 1870s and 1910, but ending up about on par just prior to the Great War in Europe. Mexico and Cuba were next in line, two-thirds to three-quarters of the Southern Cone. Nowhere in Asia did real wages come close to those in Mexico and Cuba: the three most labor-scarce Asian countries in 1909-13 -Japan, Korea and the Philippines - had real wages less than half those of Cuba and Mexico. From there, it was a big step down to the real wages and living standards prevailing for the unskilled in Colombia (Bogota) and the Brazilian Southeast (Rio de Janeiro).

\section{REAL WAGE GAPS WITHIN LATIN AMERICA: CONVERGENCE OR DIVERGENCE?}

Table 1 suggests two additional facts worth noting. It is certainly true that the real wage estimates for 1909-1913 offer strong confirmation of the historical persistence of the wealth of nations. That is, the Latin American economic hierarchy changed very little in the eighty years after 1909-1913, at least as gauged by the five in Table 1 whose GDP per capita Astorga and FitzGerald (1998) can document between 1910 and 1990; only Brazil and Cuba switched their positions in the hierarchy during the 20 th century. It appears that history and initial conditions have mattered a great deal to Latin America in this century. However, the size of the gaps between these parts of Latin America diminished dramatically. In 1910, the five poorest countries whose GDP per capita can be documented were Brazil, Ecuador, Venezuela, Colombia and Peru, from poorest on up. Setting the average of the three richest countries - Argentina, Chile 
and Cuba - at 100, the five poorest had per capita incomes of 18.8, 25, 26.3, 33.4 and 34.3. In 1990, the same calculation, and in the same order, yields relative per capita incomes of $80.7,53.2,127.7,76.7$ and 50.9. Every single one of these five Latin American countries who were poorest eighty years ago began catching up with the richest three Latin American countries thereafter, and the collapse in the gap between the richest and poorest countries was quite significant.

FIGURE 3

Dispersion of GDP per capita in Latin America 1900-1995

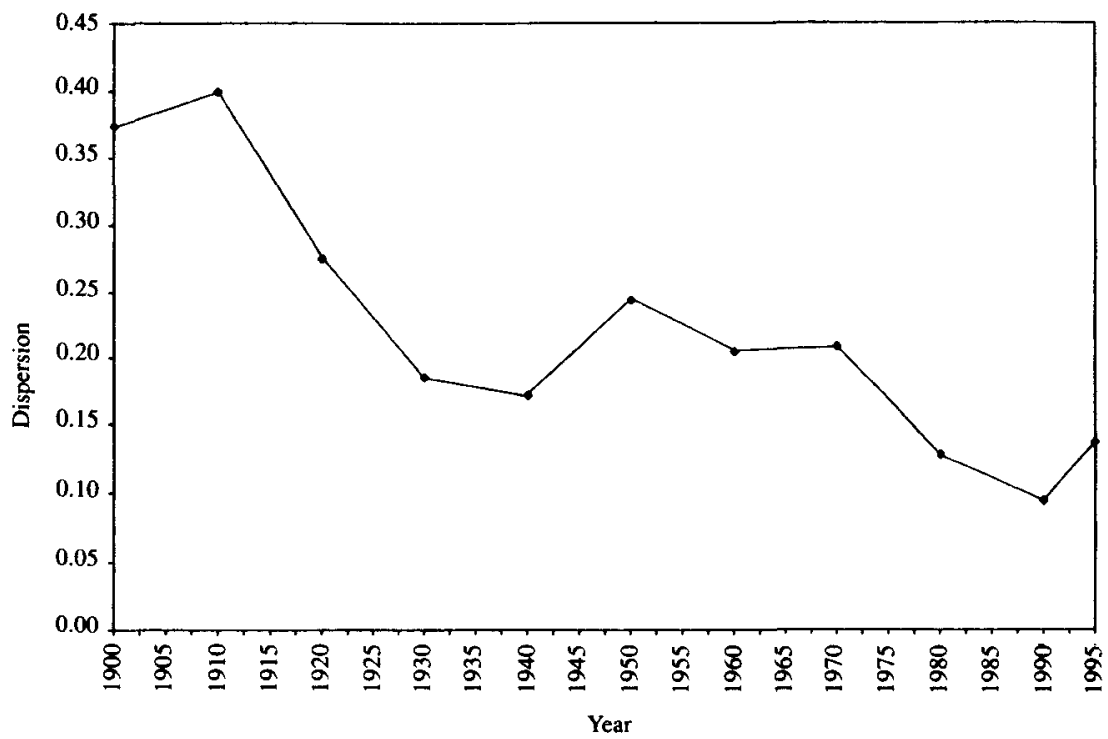

So far, the evidence points to strong economic convergence within Latin America in the 20th century. What happens if Mexico is added to the list (giving us nine observations) and a measure of dispersion, $\mathrm{C}(9)$, is calculated for every census date from 1910 to the present? The results are plotted in Figure 3 and they confirm the cruder measures of convergence offered in the previous paragraph. Between 1910 and 1930, the dispersion index drops by more than a half, from about 0.40 to 0.19 , a huge decline. The decline ceases between 1930 and 1970, after which it 


\section{FIGURE 4}

Real Wages in Latin America $(1913=100)$ : Argentina, Southeast Brazil and Uruguay

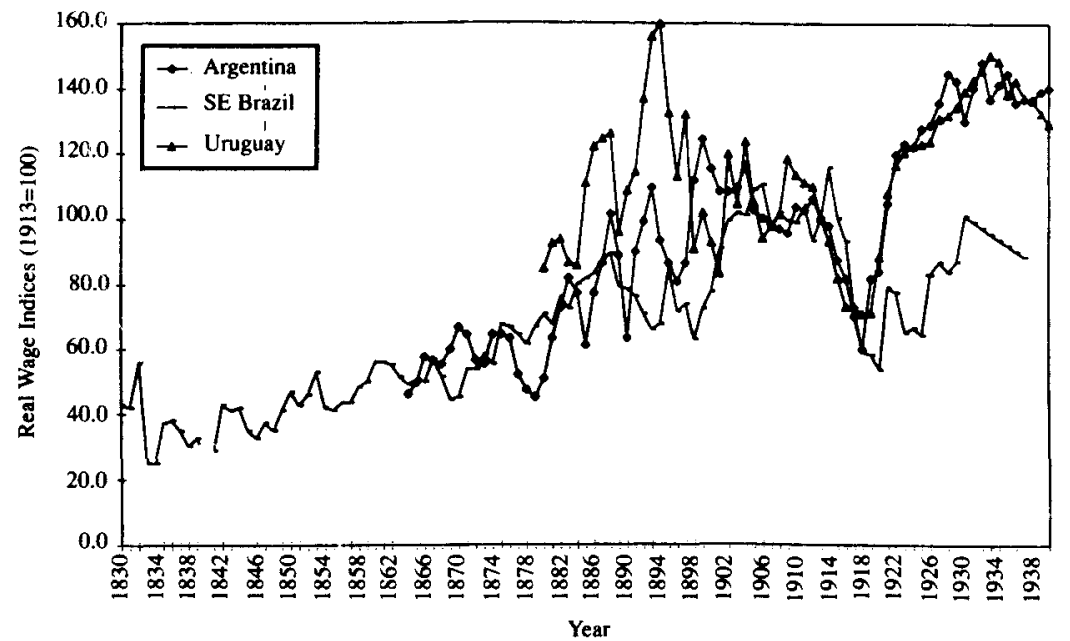

\section{FIGURE 5}

Real Wages in Latin America (1913=100): Northeast Brazil, Columbia, Cuba and Mexico

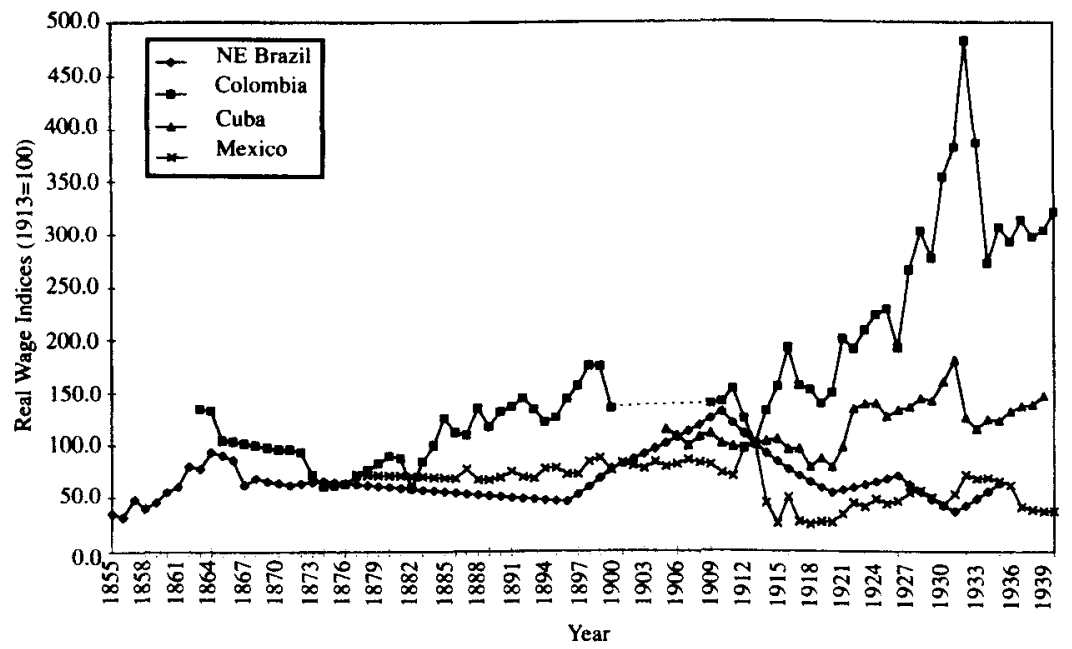


drops sharply again, to about 0.09 in 1990 . Why did this 20th century convergence within Latin America take place in two steps, and why during those epochs?

\section{FIGURE 6}

Dispersion of PPP-Adjusted Real Wages in Latin America 1864-1914

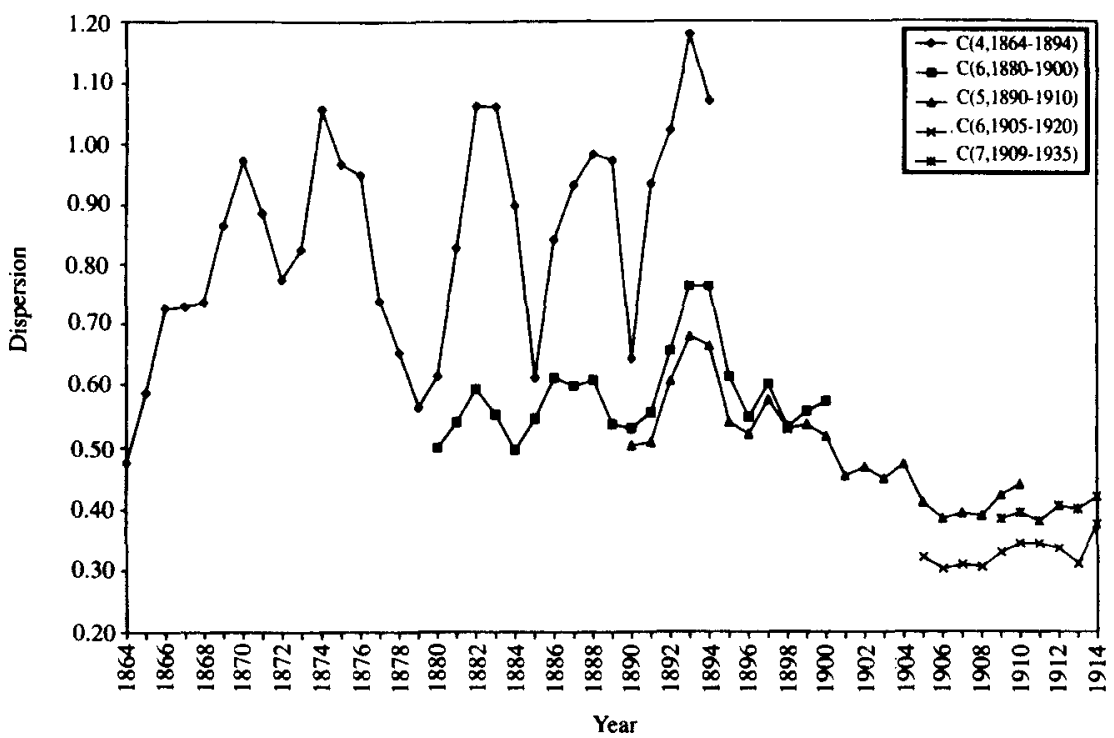

So much for this century; what about the last? Was there convergence within Latin America in the 19 th century as well? ${ }^{6}$ Here we use our real wage data, which are plotted in Figures 4 and 5 . True, the total number of countries in the 19th century sample is smaller, and there are missing years in some of the time series. While the data are imperfect, Figure 6 patches together overlapping measures of $C$ as best we can. The imperfect data seem to offer an unambiguous answer to the question at hand. There is some convergence between the mid-1890s and World War I suggested by $\mathrm{C}(5)$, so the 20th century convergence we see in Figure 3 may have had it's source in the very late 19th century. But there is absolutely no evidence of convergence in Latin America prior to the turn of the century.

"I continue to underline «within» to alert the reader that I am not yet talking about gaps between Latin America and the core. 
TABLE 2

Real Wage Performance in Latin America, 1830-1939

$(1913=100)$

\begin{tabular}{|c|c|c|c|c|c|c|c|}
\hline Period & Argentina & $\begin{array}{c}\text { Brazil, } \\
\text { Soutbeast }\end{array}$ & $\begin{array}{c}\text { Brazil, } \\
\text { Nortbeast }\end{array}$ & Colombia & Cuba & Mexico & Uruguay \\
\hline $1830-1834 \ldots \ldots \ldots$ & & 38.0 & & & & & \\
\hline $1835-1839 \ldots \ldots \ldots$ & & 34.6 & & & & & \\
\hline $1840-1844 \ldots \ldots \ldots$ & & 36.3 & & & & & \\
\hline $1845 \cdot 1849 \ldots \ldots \ldots$ & & 36.1 & & & & & \\
\hline $1850-1854 \ldots \ldots \ldots$ & & 45.9 & & & & & \\
\hline $1855-1859 \ldots \ldots \ldots$ & & 45.1 & 40.0 & & & & \\
\hline $1860-1864 \ldots \ldots \ldots$ & & 53.3 & 73.2 & & & & \\
\hline $1865-1869 \ldots \ldots \ldots$ & 55.6 & 50.4 & 74.2 & 100.8 & & & \\
\hline $1870-1874 \ldots \ldots \ldots$ & 61.4 & 53.0 & 63.8 & 83.2 & & & \\
\hline $1875-1879 \ldots \ldots \ldots$ & 54.3 & 65.3 & 62.7 & 70.8 & & & \\
\hline $1880-1884 \ldots \ldots .$. & 69.0 & 73.2 & 57.7 & 84.0 & & 70.2 & 88.5 \\
\hline $1885-1889 \ldots \ldots . .$. & 82.8 & 84.0 & 53.2 & 119.7 & & 69.9 & 115.6 \\
\hline $1890-1894 \ldots \ldots \ldots$ & 90.8 & 71.6 & 49.0 & 133.7 & & 72.3 & 135.0 \\
\hline $1895.1899 \ldots \ldots \ldots$ & 97.7 & 72.9 & 54.6 & 155.5 & & 79.1 & 113.7 \\
\hline $1900-1904 \ldots \ldots \ldots$ & 111.3 & 94.0 & 86.6 & - & & 80.1 & 104.5 \\
\hline $1905-1909 \ldots \ldots \ldots$ & 98.4 & 103.4 & 112.1 & - & 107.4 & 82.0 & 103.0 \\
\hline $1910-1914 \ldots \ldots \ldots$ & 101.8 & 102.2 & 110.2 & 130.0 & 99.5 & 76.8 & 105.2 \\
\hline $1915-1919 \ldots \ldots \ldots$ & 76.1 & 76.6 & 70.6 & 158.9 & 92.4 & 30.7 & 73.9 \\
\hline $1920-1924 \ldots \ldots \ldots$ & 110.6 & 68.4 & 58.9 & 194.2 & 117.5 & 38.5 & 110.9 \\
\hline $1925.1929 \ldots \ldots \ldots$ & 135.9 & 80.9 & 60.4 & 252.9 & 136.0 & 49.9 & 128.6 \\
\hline $1930-1934 \ldots \ldots \ldots$ & 139.3 & 97.1 & 44.9 & 375.4 & 141.1 & 60.7 & 145.4 \\
\hline $1935-1939 \ldots \ldots \ldots$ & 138.6 & & & 302.4 & 135.0 & 48.6 & 137.4 \\
\hline
\end{tabular}

SOURCES: Williamson (1998c), Appendix Tables 1-6.

Indeed, C(4) and C(6) suggest divergence up to the 1890 s, not convergence. Paul Krugman and Anthony Venables $(1990,1995)$ might view this inverted U-shaped pattern in Latin American real wage dispersion as support for their position that globalization is likely to cause divergence in early stages of development before it causes convergence in later stages. However, industrialization is central to the Krugman-Venables model and it is not clear that it was the central force accounting for divergence in 19th century Latin America. Perhaps instead it might be that the richer parts of Latin America, which had closer commercial ties with North America and Europe, 
TABLE 3

Real Wage in Latin America Relative to Great Britain, 1830-1939 (in percent)

\begin{tabular}{|c|c|c|c|c|c|c|c|}
\hline Period & Argentina & $\begin{array}{c}\text { Brazil, } \\
\text { Southeast }\end{array}$ & $\begin{array}{c}\text { Brazil, } \\
\text { Northeast }\end{array}$ & Colombia & Cuba & Mexico & Unuguay \\
\hline $1830-1834 \ldots \ldots \ldots$ & & 14.9 & & & & & \\
\hline $1835-1839 \ldots \ldots \ldots$ & & 14.1 & & & & & \\
\hline $1840-1844 \ldots \ldots \ldots$ & & 14.0 & & & & & \\
\hline $1845-1849 \ldots \ldots \ldots$ & & 13.2 & & & & & \\
\hline $1850-1854 \ldots \ldots \ldots$ & & 16.2 & & & & & \\
\hline $1855-1859 \ldots \ldots \ldots$ & & 16.8 & 4.4 & & & & \\
\hline $1860-1864 \ldots \ldots \ldots$ & & 20.4 & 8.3 & & & & \\
\hline $1865-1869 \ldots \ldots \ldots$ & 81.8 & 17.2 & 7.6 & 28.6 & & & \\
\hline $1870-1874 \ldots \ldots \ldots$ & 86.5 & 17.3 & 6.2 & 22.6 & & & \\
\hline $1875-1879 \ldots \ldots \ldots$ & 65.8 & 18.2 & 5.2 & 16.3 & & & \\
\hline $1880-1884 \ldots \ldots \ldots$ & 81.2 & 19.9 & 4.7 & 19.0 & & 66.5 & 95.4 \\
\hline $1885-1889 \ldots \ldots \ldots$ & 85.3 & 20.0 & 3.8 & 23.8 & & 58.1 & 109.2 \\
\hline $1890-1894 \ldots \ldots \ldots$ & 87.8 & 16.1 & 3.3 & 25.0 & & 56.4 & 119.2 \\
\hline $1895-1899 \ldots \ldots \ldots$ & 85.9 & 14.8 & 3.3 & 26.3 & & 56.0 & 91.8 \\
\hline $1900-1904 \ldots \ldots \ldots$ & . 101.0 & 19.7 & 5.4 & - & & 58.4 & 86.8 \\
\hline $1905-1909 \ldots \ldots \ldots$ & . $\quad 92.0$ & 22.3 & 7.2 & - & 76.2 & 61.7 & 88.2 \\
\hline $1910-1914 \ldots \ldots \ldots$ & . 100.8 & 23.4 & 7.4 & 24.8 & 74.8 & 60.6 & 95.2 \\
\hline $1915-1919 \ldots \ldots \ldots$ & 91.1 & 21.5 & 5.8 & 36.9 & 84.3 & 30.0 & 81.0 \\
\hline $1920-1924 \ldots \ldots \ldots$ & . 103.9 & 14.8 & 3.8 & 35.0 & 84.0 & 29.1 & 95.3 \\
\hline $1925-1929 \ldots \ldots \ldots$ & . 125.5 & 17.2 & 3.8 & 44.9 & 95.3 & 37.0 & 108.7 \\
\hline $1930-1934 \ldots \ldots \ldots$ & . 116.6 & 18.8 & 2.6 & 60.5 & 89.9 & 40.7 & 111.4 \\
\hline $1935-1939 \ldots \ldots \ldots$ & . 115.2 & & & 48.4 & 85.1 & 32.4 & 104.4 \\
\hline
\end{tabular}

SOURCES AND Notes: See notes to Table 1.

were also favored by bigger improvements in transport connections between them and the core. I leave this question on the agenda for future research.

REAL WAGE GAPS BETWEEN CORE AND PERIPHERY: CONVERGENCE OR DIVERGENCE DURING THE FIRST GREAT GLOBALIZATION BOOM?

In spite of convergence within Latin America between 1910 and 1995, there was divergence between Latin America and the world leaders. All 
TABLE 4

Real Wage Performance in Latin America by Decades Relative to Great Britain, and the Mediterranean Basin, 1830s-1939s

\begin{tabular}{|c|c|c|c|c|c|c|c|}
\hline Period & Argentina & $\begin{array}{c}\text { Brazil, } \\
\text { Southeast }\end{array}$ & $\begin{array}{c}\text { Brazil, } \\
\text { Nortbeast }\end{array}$ & Colombia & Cuba & Mexico & Uruguay \\
\hline \multicolumn{8}{|c|}{ A. Relative to Great Britain } \\
\hline 1830 s..................... & & 14.5 & & & & & \\
\hline $1850 \mathrm{~s} \ldots \ldots \ldots \ldots \ldots$ & & 16.5 & & & & & \\
\hline 1870 s.................... & 76.2 & 17.7 & 5.7 & 19.5 & & & \\
\hline 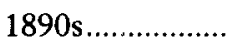 & 86.8 & 15.5 & 3.3 & 25.7 & & 56.2 & 105.5 \\
\hline $1909-1913 \ldots \ldots \ldots$ & 97.9 & 22.0 & 7.7 & 24.5 & 73.9 & 65.3 & 97.4 \\
\hline 1930 s.................... & 115.9 & & & 54.4 & 87.5 & 36.6 & 107.9 \\
\hline
\end{tabular}

B Relative to Weighted Average of Italy, Portugal, and Spain

\begin{tabular}{|c|c|c|c|c|c|c|c|}
\hline $1830 \mathrm{~s} . . . \ldots \ldots \ldots \ldots \ldots$ & & 30.5 & & & & & \\
\hline 1850 s.................... & & 35.8 & & & & & \\
\hline 1870 s....................... & 207.7 & 48.9 & 15.5 & 53.1 & & & \\
\hline 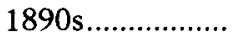 & 267.8 & 47.5 & 10.1 & 79.1 & & 173.2 & 324.8 \\
\hline $1909-1913 \ldots \ldots \ldots$ & 212.1 & 47.8 & 16.8 & 53.1 & 160.5 & 140.9 & 211.5 \\
\hline $1930 \mathrm{~s} . . . . . . . . . . . . . . . . .$. & 201.1 & & & 94.4 & 152.2 & 63.0 & 187.0 \\
\hline
\end{tabular}

C Per Annum Growth Rate (\%)

\begin{tabular}{lllllllll}
\hline $1830 \mathrm{~s}-1850 \mathrm{~s} . . . .$. & & 1.27 & & & & & \\
$1850 \mathrm{~s}-1870 \mathrm{~s} \ldots . .$. & & 1.50 & & & & & \\
$1870 \mathrm{~s}-1890 \mathrm{~s} \ldots . .$. & 3.15 & 1.11 & -0.90 & 4.39 & & & \\
$1890 \mathrm{~s}-1909 / 13 .$. & 0.46 & 2.24 & 7.58 & -0.55 & & 0.67 & -0.69 \\
$1909 / 13-1930 \mathrm{~s} .$. & 1.58 & & & 6.72 & 1.56 & -1.49 & 1.20 \\
\hline
\end{tabular}

SourCes AND Notes: For panel A, see notes to Table 1. For panel B, see Williamson (1998c), Appendix Table 7.4 for PPP-adjusted Latin American real wages where emigrating Mediterranean countries in $1913=100$. The real wage series for the emigrating Mediterranean countries (Italy, Portugal, and Spain) is a weighted average of the respective real wage indices of these three countries, where the weights used were the 1913 populations of these countries found in Maddison 1995. For more details, see the text preceding Appendix Table 7.4. Panel $\mathrm{C}$ is based on the real wage data in Williamson (1998c), Appendix Tables 1-6. 
six parts of Latin America documented in Table 1 for 1909-13 lost ground relative to Britain in this century ${ }^{7}$, some of them a great deal of ground. But what about prior to the Great War? Was the 19th century different?

\section{FIGURE 7}

Real Wages in Latin America relative to Great Britain (in percent) Argentina, Southeast Brazil, and Uruguay

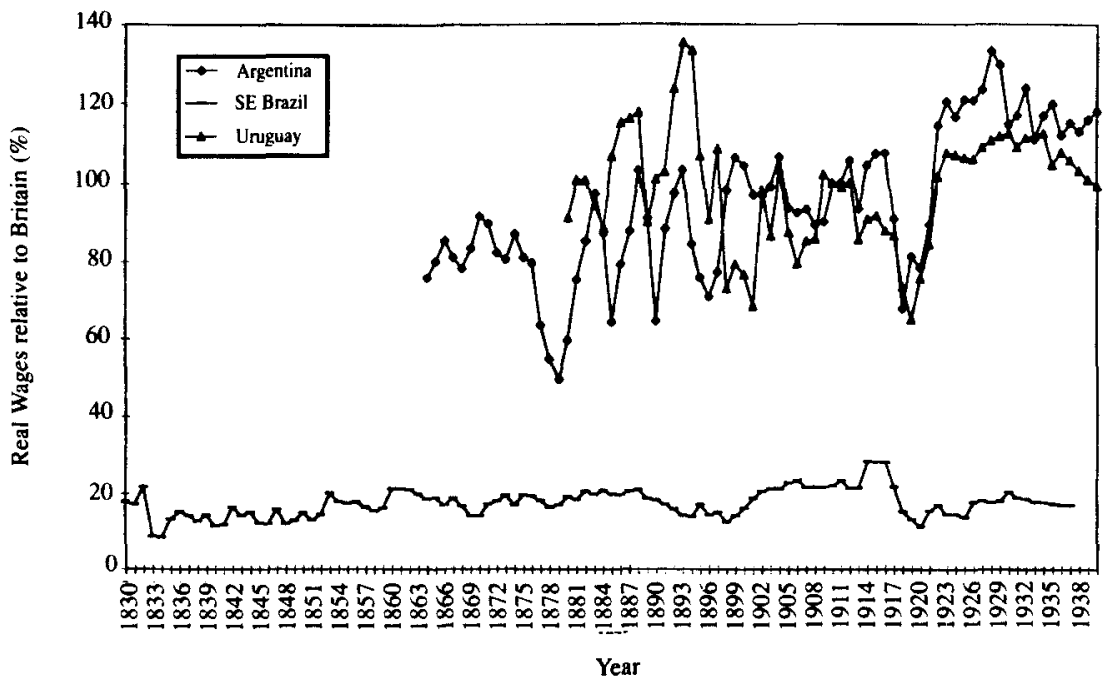

Table 3, Table 4 and Figure 7 all document that Argentina was catching up with Britain in the half-century before World War I. There is evidence that the Brazilian Southeast started catching up from mid-century. But catch up with the European leaders doesn't seem to have been taken place anywhere else in Latin America (see also Figure 8). Table 3 shows clearly that Colombia, Mexico and Uruguay were able to hold their own up to the Great War, but real wages there do not show catching up with those in Britain. Nor is there any evidence of catching up in the Brazilian Northeast or in Cuba.

${ }^{7}$ Since rich countries are supposed to grow more slowly than poor ones, United States growth experience up to 1940 must be viewed as unusually fast -bucking the convergence tide (Williamson 1995). Thus, it makes far more sense to compare the Latin America periphery with the European core, like Britain. 


\section{FIGURE 8}

Real Wages in Latin America relative to Great Britain (in percent) Nortbeast Brazil, Colombia, Cuba, and Mexico

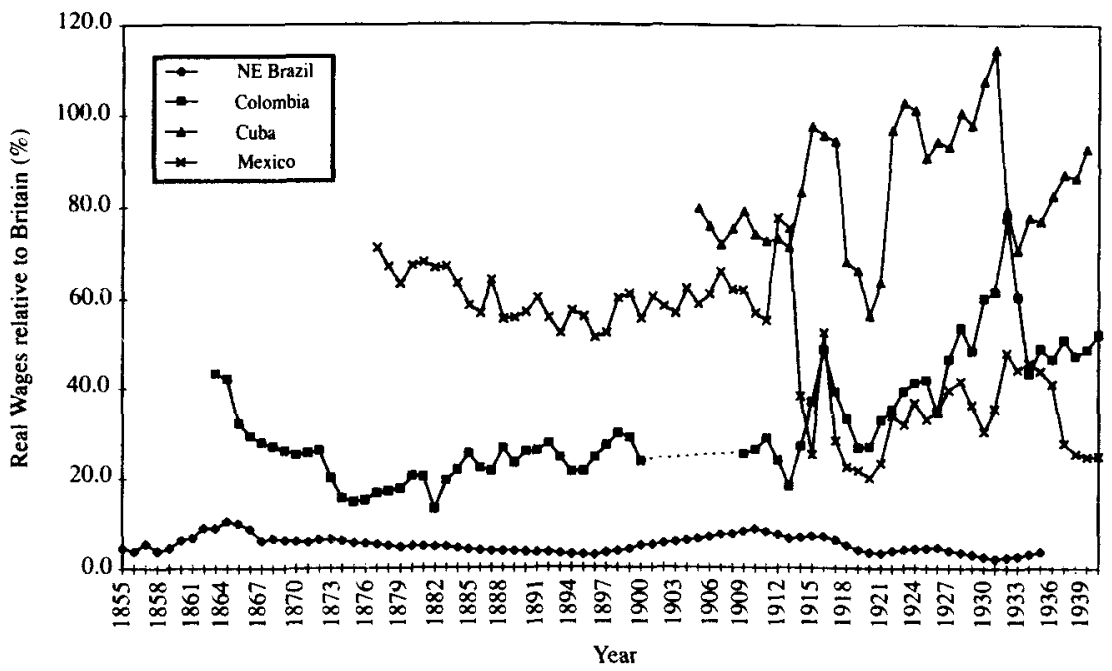

While there is very little evidence of Latin American catch up on the world's leaders prior to 1914 , at least Latin America was able to hold its own. In contrast, there is plenty of evidence of fall back in the 20th century. Why the difference between the two centuries? What were the economic and demographic fundamentals present during the first great globalization boom which were absent thereafter? The literature points, of course, to policy in accounting for the great divide. Relative to the world leaders, better growth performance in Latin America prior to the 1920 s then afterwards seems to be highly correlated with an open policy on one side of that divide and a closed policy on the other. But any agenda whose goal is to isolate the role of policy in accounting for the different growth experience on either side of 1914 needs to control for everything else that might matter, especially those factors that must have influenced policy - demography, bad luck in world factor markets, bad luck in world commodity markets, the tyranny of distance and other forces. 


\section{REAL WAGE GAPS AND MIGRATION BETWEEN THE OLD AND NEW WORLD}

The fact that Italian, Portuguese and Spanish emigrants were poor by western European standards, and that so many went to Latin America, has generated debate on the receiving end. Sir Arthur Lewis thought that his model of development (Lewis 1954) with immigrant-augmented elastic labor supplies applied to late 19th century Latin America (Lewis 1978a), and many Latin American scholars subsequently agreed. Carlos DiazAlejandro (1970) wrote that the labor supply in Argentina before 1930 was «perfectly elastic at the going wage (plus some differential) in the industrial centers of Italy and Spain». Nathaniel Leff (1992) thought the same was true of the Brazilian Southeast and that elastic immigrant labor supplies could account for stable wages in Sao Paulo and Santos from the 1880s onwards. If the elastic labor supply thesis is correct, then late 19th century Latin emigration should have been far more responsive to wage gaps between home and abroad compared with the early emigrants from northwest Europe going to North America, Australia and New Zealand. What seems like a plausible hypothesis has, however, been soundly rejected: Latin emigrants were no more responsive to wage gaps between home and abroad than was the case for other European emigrants (Hatton and Williamson 1994; 1998). It is simply not true that the Latin economies in the late 19th century had more elastic emigrant labor supplies than the rest of Europe. This revisionist finding is consistent with Alan Taylor's (1994) research which shows that Argentina's immigration was no more responsive to wage gaps than was Australia's. This new evidence does not imply that European migrants going to Latin America were unresponsive to wage gaps, but it does do heavy damage to the arguments of Sir Arthur Lewis (1978a) and Carlos Diaz-Alejandro (1970) that Latin American development took place under uniquely elastic labor supplies. They were not uniquely elastic.

Without the wage gaps favoring the more labor scarce parts of Latin America, the Mediterranean migrants would never have come. And the labor scarce parts were certainly the ones which mattered. As Figure 9 suggests, the Latin American wage advantage over the western and central Mediterranean (a population weighted average of Italy, Portugal and Spain ${ }^{8}$ ) collapsed from the early 1890 s to World War I. In fact, by 1918

${ }^{8}$ These weights seem appropriate given what we know about the origin of the foreign-born in the major immigrating areas of Latin America. Between 1891 and 1910, 


\section{FIGURE 9}

\section{Real Wage Gap Between Latin America and the Emigrating Mediterranean Contries}

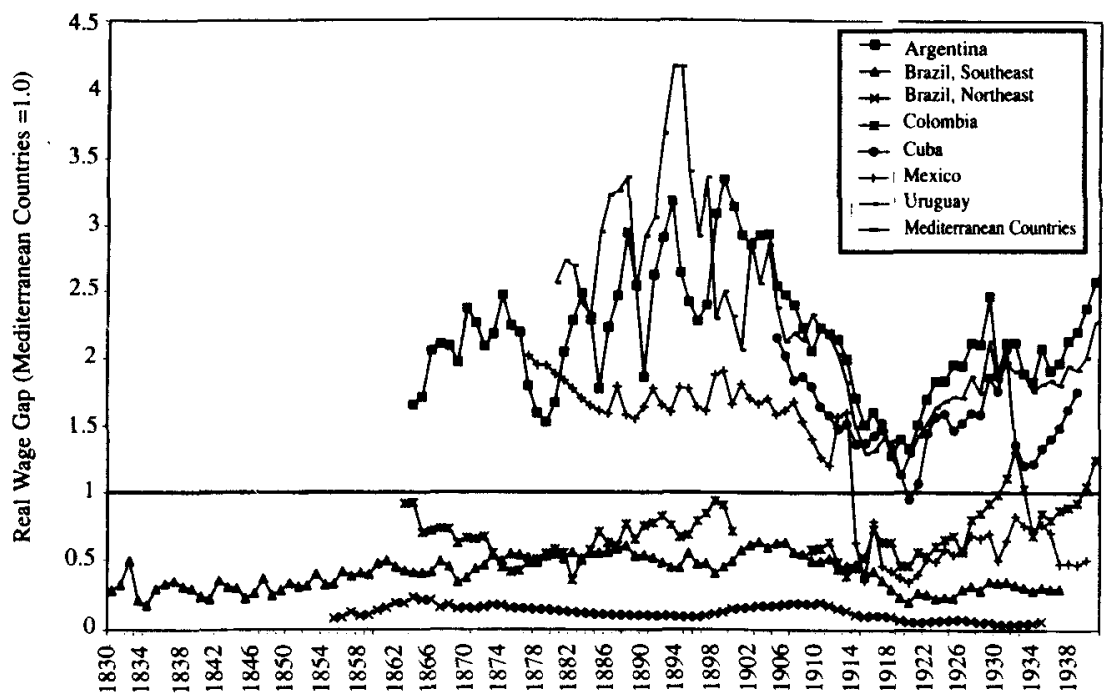

Year

there was very little real wage advantage that Argentina, Uruguay and Cuba had to offer potential emigrants from the western and central Mediterranean, and Mexico had fallen way behind. There was a lively Latin America rebound in the 1920s and 1930s, but the high wage leaders -Cuba, Mexico and the Southern Cone- never regained their late 19th century advantage. This is one reason why Latin American immigration fell off in the interwar decades. Another reason, of course, is that the immigrating countries adopted less generous subsidies and in some cases outright hostile policies towards the European emigrants. However, this policy switch in Latin America was in part driven by the erosion of relative labor scarcity, a rise in inequality, and a competitive response to U.S. quota restrictions, also driven by rising inequality there (Timmer and Williamson 1998).

Italians and Spaniards made up about 85 percent of the total immigrants entering Argentina (Sánchez-Albornoz 1974, p. 160). Between 1819 and 1959, Portuguese, Italians and Spaniards made up almost three quarters of Brazilian immigration (Sánchez-Albornoz 1974, p. 161). And between 1902 and 1918, Spaniards made up almost 82 percent of Cuban immigrants (Sánchez-Albornoz 1974, p. 167). 
Prior to 1914, the size of the gaps also had an important impact on where the immigrants went in Latin America. Table 1 and Figure 9 suggest the biggest immigration rates should have been recorded by the Southern Cone, illustrated by Argentina and Uruguay. The next biggest rates should have been recorded by Cuba, followed by Mexico, followed far behind by the others. The problem is that the comparative immigration data for Latin America isn't good enough to perform a strict test of what seems to be a plausible hypothesis. Yet, imperfect data in Table 6 confirm it. In the 1870 s and 1880 s, the immigration rates in Argentina were five to six times those of Brazil. Even if we assume that all the Brazilian immigrants went to the Southeast, the immigration rates into the Brazilian Southeast in the 1870 s would still have been less than half that of Argentina ${ }^{9}$. By the first decade of the present century, Argentina had the highest immigration rates in the New World. Cuba was in second place, even higher than the United States. Brazil was in last place, one quarter of Cuba and one tenth of Argentina. As for the (poorly-documented) rest, Nicholas Sanchez-Albornoz (1974) reports that the Mexican census of 1900 recorded only 0.5 percent foreign-born, the Venezuelan share was only 4 percent in 1891, and even the Chilean share was only 4.7 percent in 1907 . It certainly seems like «the tide of migration ... flowed only toward the most developed areas» of Latin America (Sánchez-Albornoz 1974), and, it might be added, the tide also seemed to be deflected by the tyranny of distance.

There is, of course, another way to explore this correlation. Did high wage regions in Latin America have higher rates of population and labor force growth than low wage regions? The immigrations from Europe would have helped yield that result, as we have seen. But the domestic population response should have reinforced the immigration response: the more labor scarce and high wage regions should have had economic conditions which encouraged couples to marry younger and to have more children, and the children should have been more likely to survive. Figure 10 confirms the hypothesis for the period 1850-1940: here the rate of population growth is regressed on the initial real wage; the estimated coefficient is 0.012 , and the $t$-statistic is 2.22 . Of course, the finding that high wages today encourages a positive labor supply response tomorrow does not necessarily imply a rejection of the Malthusian proposition that a swollen population today, with fixed resources, implies diminishing returns, declining real wages

9 The Brazilian Southeast share of total Brazilian population in 1872 was about 40 percent (Leff 1972, p. 253). 


\section{TABLE 5}

Real Wages in Latin America Relative to Argentina, 1830-1939 (in percent)

\begin{tabular}{|c|c|c|c|c|c|c|}
\hline Period & $\begin{array}{c}\text { Brazil, } \\
\text { Southeast }\end{array}$ & $\begin{array}{c}\text { Brazil, } \\
\text { Nortbeast }\end{array}$ & Colombia & Cuba & Mexico & Uruguay \\
\hline 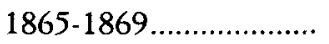 & 21.0 & 9.2 & 35.0 & & & \\
\hline $1870-1874 \ldots \ldots \ldots \ldots \ldots \ldots$ & 20.2 & 7.2 & 26.2 & & & \\
\hline $1875 \cdot 1879 \ldots \ldots \ldots \ldots \ldots \ldots$ & 28.3 & 8.1 & 26.1 & & & \\
\hline $1880-1884 \ldots \ldots \ldots \ldots \ldots \ldots$ & 25.1 & 5.9 & 24.2 & & 84.3 & 120.7 \\
\hline $1885-1889 \ldots \ldots \ldots \ldots \ldots \ldots$ & 24.0 & 4.5 & 28.6 & & 69.9 & 131.1 \\
\hline $1890-1894 \ldots \ldots \ldots \ldots \ldots \ldots$ & 19.1 & 3.8 & 29.3 & & 66.2 & 137.5 \\
\hline $1895-1899 \ldots \ldots \ldots \ldots \ldots \ldots$ & 17.8 & 3.8 & 31.0 & & 66.2 & 111.5 \\
\hline $1900-1904 \ldots \ldots \ldots \ldots \ldots \ldots$ & 19.5 & 5.3 & - & & 57.9 & 86.0 \\
\hline $1905-1909 \ldots \ldots \ldots \ldots \ldots \ldots$ & 24.3 & 7.8 & - & 82.9 & 67.1 & 95.9 \\
\hline 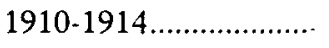 & 23.2 & 7.4 & 24.6 & 74.2 & 60.4 & 94.5 \\
\hline $1915-1919 \ldots \ldots \ldots \ldots \ldots \ldots$ & 23.2 & 6.4 & 40.8 & 92.9 & 32.5 & 90.2 \\
\hline $1920-1924 \ldots \ldots \ldots \ldots \ldots \ldots$ & 14.4 & 3.7 & 33.9 & 79.8 & 27.8 & 92.2 \\
\hline $1925-1929 \ldots \ldots \ldots \ldots \ldots \ldots$ & 13.7 & 3.1 & 35.7 & 76.0 & 29.5 & 86.7 \\
\hline $1930-1934 \ldots \ldots \ldots \ldots \ldots \ldots$ & 16.1 & 2.2 & 51.8 & 77.2 & 34.9 & 95.6 \\
\hline $1935-1939 \ldots \ldots \ldots \ldots \ldots \ldots$ & & & 42.0 & 74.0 & 28.1 & 90.7 \\
\hline
\end{tabular}

SOURCES: Williamson (1998c), Appendix Table 7.1.

and living standards tomorrow. I will come back to this issue at the end. of this section.

Thus, the fact that labor supplies to Argentina and Brazil were not perfectly or even uniquely elastic did not imply that the immigrations were small or that they failed to have an impact on population and labor force growth. However, there are other reasons why the migrations to the Southern Cone, at least, were mass. A boom in the natural rate of population increase two decades earlier was a very powerful force serving to push up emigration rates in Italy and Portugal, experience on the upswing of the demographic transition that was replicated in the rest of Europe earlier in the century. While there was still a wage gap favoring the Southern Cone two to one, these demographic events were by far the most powerful forces accounting for the surge in Italian and Portuguese emigration rates after the 1880s. Spain, however, is an exception: rates of natural increase were falling in the 1870 s and 1880 s, not rising (Moreda 1987). If emi- 
FIGURE 10

The Long-Run Labor Supply Response: Correlation Between the Initial Real Wage and Subsequent Population Growth 1850-1940

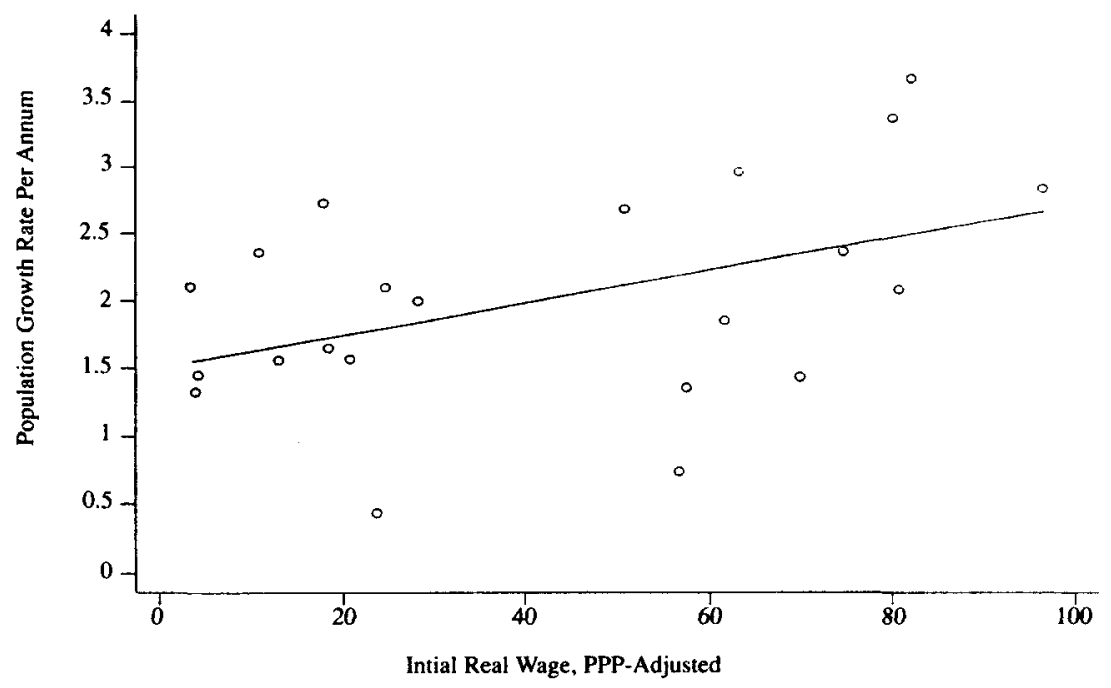

grant-inducing demographic forces were absent in Spain after the 1880s, why the rise in Spanish emigration rates? The answer seems to lie largely with economic failure at home. The wage gap between Spain and destination countries remained enormous: the ratio of Argentine to Spanish real wages was 2.3 in $1885,3.1$ in $1895,3.6$ in 1905 and 2.5 in 1913. This fact explains almost all of the surge in Spanish emigration. The same was true of Portugal, although the failure at home was not nearly as great. In contrast, Italian wages were catching up with those in destination countries - Argentina, Germany and the United States - and that wage success muted the surge in Italian emigration by partially offsetting those powerful emigrant-inducing demographic forces.

For all three Latin countries, there were additional underlying fundamentals that they shared and which served to contribute to the surge in emigration: modest rates of industrialization (e.g., slow rates of «good» job creation) and rising migrant populations abroad which sent remittances home. Nonetheless, what really made the Latin countries in the Mediterranean different after the 1880 s was the delayed demographic transition 
and the economic failure in Portugal and Spain. Furthermore, Blanca Sanchez-Alonso (1998; 1999 forthcoming) has stressed the role that policy played in creating an even poorer emigration environment in Spain. While the rest of the world stuck with the gold standard, Spain depreciated the peseta (and raised tariffs on cereals) so that Spanish agriculture could compete with foreign imports in the domestic market. This policy served to raise the demand for unskilled labor at home and to reduce emigration push, but it also made the cost of the move overseas more expensive.

So, it was not elastic labor supply responses to wage gaps that produced the mass migrations from the western and central Mediterranean to Argentina, Chile, Uruguay and the Brazilian Southeast. Rather, it was demographic events and economic failure in the Mediterranean. And these mass migrations mattered, just as they did in so many other parts of the Atlantic Economy. The poorest European countries tended to have the highest emigration rates, the richest new world countries tended to have the highest immigration rates, while the European industrial leaders and the poorest new world laggards both tended to lie in the middle with net migration close to zero. Where we can measure it, big migrations translated into big labor force impact in both sending and receiving regions (Taylor and Williamson 1997; O'Rourke and Williamson 1997; Williamson 1998d): mass migration after 1870 served to augment the 1910 combined new world labor force in Argentina, Australia, Brazil, Canada, and the United States by an enormous 49 percent, to reduce the 1910 labor force in the emigrant countries around the poor European periphery (including Iberia and Italy) by a very large 22 percent, and, where the net migrations were much more modest, to reduce the 1910 labor force in the European industrial core by tiny 2 percent. Mass migration by itself probably explained from 50 to 70 percent of the real wage convergence in the late 19th century Atlantic economy (Taylor and Williamson 1997; O'Rourke and Williamson 1999).

This late 19th century Atlantic economy sample just discussed includes Argentina and Brazil, but no other Latin American countries. What role did mass migration play elsewhere in Latin America? Since we have already seen that the migration data is poor for the rest of Latin America, we will have to make do with cruder population data. While Figure 10 and Table 6 confirmed that rich Latin American countries had the highest rates of immigration and population growth, we now ask a different question: Did immigration and population growth tend to erode the wage advantage in the more labor scarce Latin American economies? To get an answer, 
TABLE 6

New World Inmigration Rates by Decade

(per 100 mean population)

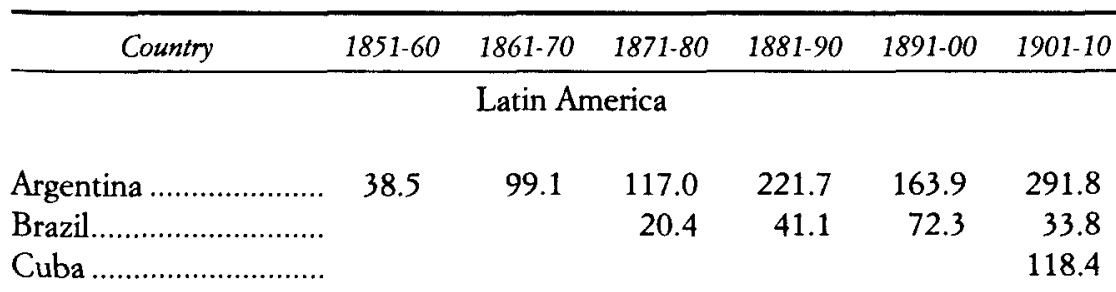

Other New World

\begin{tabular}{lrrrrrr} 
Australia..................... & & 122.2 & 100.4 & 146.9 & 7.3 & 9.9 \\
Canada..................... & 99.2 & 83.2 & 54.8 & 78.4 & 48.8 & 167.6 \\
United States............. & 92.8 & 64.9 & 54.6 & 85.8 & 53.0 & 102.0 \\
\hline
\end{tabular}

SourcE: Hatton and Williamson (1998: Table 2.2) based on Ferenczi and Willcox (1929: 209); Taylor (1992: Appendix Table 1.A2).

we borrow from the new empirical growth theory and regress per annum real wage growth on the real wage at the start of the period (giving poor countries the chance to exhibit «catch-up» on the rich), the rate of population growth (giving diminishing returns a chance to exhibit its effects), and a dummy for the pre-1919 versus the post-1918 years (giving the boom and bust in the world economy a chance to have its influence on growth performance in Latin America). The results for 1850-1940 suggest that the determinants of Latin American growth prior to World War II were far too complex to be captured very effectively by this simple model (estimated coefficient, with t-statistics in parentheses):

$$
\begin{array}{ll}
\text { initial real wage } & -0.015(0.918) \\
\text { dummy }=1 \text { if }<1919 & +2.974(3.165) \\
\text { population growth } & +1.790(2.895)
\end{array}
$$

First, there is no evidence of catching up within Latin America - the sign is right on the initial real wage, but the t-statistic too low- a finding that repeats what we reported earlier in this essay. Second, the coefficient on the dummy variable confirms that growth was far faster before 1919 than after, a result which is certainly consistent with positive price shocks 
favoring Latin America during the first great globalization boom. Third, there appears to be absolutely no evidence of diminishing returns since the significant coefficient on population growth is positive, not negative. However, it should be pointed out that we really need information on the rate of labor force growth (missing from the Latin American 19th century data base), not population growth. After all, Latin American countries with fast rates of population growth also had big immigration rates. Since immigrants were mostly young adults, rapid population growth meant a rise in the labor participation rate, and this may have favored economic growth (Bloom and Williamson 1998; Williamson 1998d).

\section{WAGE-RENTAL RATIOS AND INEQUALITY TRENDS IN THE SOUTHERN CONE}

Eli Heckscher and Bertil Ohlin argued that the integration of global commodity markets would lead to convergence of international factor prices, as countries everywhere expanded the production and export of commodities which used their abundant (and cheap) factor intensively. The only historical evidence for Latin America that I am aware of, wage-rental ratio trends from Argentina (O'Rourke, Taylor and Williamson 1996) and from Uruguay (Bertola et al. 1999), seems to be consistent with Heckscher and Ohlin. They appear in Table 7.

The trade boom between the 1870s and World War I led to falling wage-rental ratios in relatively land-abundant Argentina and Uruguay, just as Heckscher and Ohlin would have predicted. As the exports of land-intensive products boomed, so did the demand for land and thus rents. As the imports of labor-intensive manufactured products also boomed, the demand for labor fell, at least relative to land, and thus so did the wage-rental or the wage-land-value ratio. Where $1913=1.0$, the wage-rental (or the wage-land-value) ratio plunged from about 6.9 to about 0.6 between 1880-1884 and 1915-1919 in Argentina, and from 11.1 to 1.2 between 1870-1874 and 1915-1919 in Uruguay. Alternatively, the ratio of land rents to wages soared by about ten times over these four or five decades. This is a huge change in the relative scarcity of land and labor. As it turns out, these trends were typical everywhere in the land-abundant periphery, like Australia and North America (O'Rourke, Taylor and Williamson 1996) or Thailand or the Punjab (Williamson 1998a), where the possibility of trade with the core was being exploited. Exactly the opposite trends were 


\section{TABLE 7}

Argentine and Uruguay Wage/Land-Value Trends 1870

$$
(1913=1.0)
$$

\begin{tabular}{|c|c|c|}
\hline Period & $\begin{array}{c}\text { Argentina } \\
\text { W/Land Value }\end{array}$ & $\begin{array}{c}\text { Uruguay } \\
\text { W/Land Value }\end{array}$ \\
\hline $1870-1874 \ldots \ldots \ldots \ldots \ldots \ldots$ & & 11.1248 \\
\hline $1875-1879 \ldots \ldots \ldots \ldots \ldots \ldots$ & & 8.9130 \\
\hline $1880-1884 \ldots \ldots \ldots \ldots \ldots \ldots$ & 6.9115 & 7.2825 \\
\hline $1885-1889 \ldots \ldots \ldots \ldots \ldots \ldots$ & 4.0139 & 4.0021 \\
\hline $1890-1894 \ldots \ldots \ldots \ldots \ldots \ldots$ & 4.3427 & 3.7719 \\
\hline $1895.1899 \ldots \ldots \ldots \ldots \ldots \ldots$ & 3.7043 & 3.0361 \\
\hline $1900-1904 \ldots \ldots \ldots \ldots \ldots \ldots$ & 3.4503 & 2.3299 \\
\hline $1905-1909 \ldots \ldots \ldots \ldots \ldots \ldots$ & 1.6100 & 1.6777 \\
\hline $1910-1914 \ldots \ldots \ldots \ldots \ldots \ldots$ & 1.0001 & 1.1788 \\
\hline $1915-1919 \ldots \ldots \ldots \ldots \ldots \ldots$ & 0.6379 & 1.2083 \\
\hline $1920-1924 \ldots \ldots \ldots \ldots \ldots$ & 0.6324 & 1.5026 \\
\hline $1925-1929 \ldots \ldots \ldots \ldots \ldots \ldots$ & 0.6072 & 1.5018 \\
\hline $1930-1934 \ldots \ldots \ldots \ldots \ldots \ldots$ & 0.6951 & 1.7434 \\
\hline $1935-1939 \ldots \ldots \ldots \ldots \ldots \ldots$ & 0.7089 & 2.1353 \\
\hline
\end{tabular}

SouRCES: The series for Argentina is from Williamson (1998c), Appendix Table 1.4. The series for Uruguay is from Bértola et al. (1999).

taking place in Europe, especially in those parts of Europe which stuck to their free trade guns: i.e., wage-rental ratios soared in Britain, Ireland and Scandinavia. To the extent that land holdings were highly concentrated at the top, these trends clearly implied rising inequality in Argentina and Uruguay, but falling inequality in Europe. Furthermore, when the world economy fell apart after World War I, the steep decline in the wage-rental ratio stopped in Argentina and Uruguay and actually began to rise in the 1930s (Table 7). Presumably, inequality trends reversed as well.

So much for factor demand and globalization. What about factor supply? As we pointed out above, W. Arthur Lewis (1954) used his famous labor surplus model to show how early industrialization could create inequality (and also a rising surplus to finance domestic-savings-constrained accumulation). Stable real wages implied rising profit shares economy-wide. According to his model, the worker fails to share in GDP per capita growth since elastic labor supplies keep wages and living standards stable. The 
Lewis model is quiet about what happens to land rents, but the classical model from which it was derived clearly predicted a rise. As we have seen, Diaz-Alejandro (1970), on Argentina, and Leff (1972; 1992), on Brazil, both have used the labor surplus model to predict stable real wages in Latin America, appealing to the migration of surplus labor from the Mediterranean. While the thesis that these parts of Latin America had more elastic labor supplies is rejected, they did have higher rates of immigration and labor force growth. This process of intensification may have suppressed real wage growth relative to other factor prices like land rents. After all, and in spite of land settlement, labor supplies were more elastic than land supplies, and land/labor ratios fell in the Southern Cone. Meanwhile, rising export prices raised land rents and land values. Note also that the fact that mass migrations into Argentina and Uruguay dropped off sharply after World War I is consistent with the turn-around in the wage-rental ratio drift in Table 7.

It follows that the Heckscher-Ohlin globalization model and the Lewis labor-surplus model both predict falling wage-rental ratios and rising inequality in the globalizing Southern Cone prior to World War I, and the opposite thereafter. Thus, discriminating empirically between these two competing views will prove difficult since both were at work. Regardless of which thesis explains Southern Cone history best, we need to know whether this experience was ubiquitous across Latin America.

\section{HINTS AND HUNCHES ABOUT INEQUALITY TRENDS IN LATIN AMERICA}

Complete income distributions at various benchmarks between the mid-19th century and World War II are unavailable for any Latin American country, including Argentina and Uruguay. But even if such data were available, it is not obvious that they would offer the best way to search for the underlying causes of changing inequality. Our interest here is factor prices: wages, land rents and premium on skills. How did the typical unskilled worker near the bottom of the distribution do relative to the typical landowner or capitalist near the top, or even relative to the typical skilled blue collar worker or educated white collar employee near the middle? The modern debate over OECD inequality has a fixation on wages, but since land and landed interests were far more important to late 19th century inequality trends - especially in the more agrarian Latin America- we 
need to add them to our distribution inquiry. In any case, there are two kinds of evidence available to document inequality trends in Latin America prior to 1940: trends in the wage-rental ratio, which we have already explored, but, sad to say, are limited to Argentina and Uruguay; and trends in the ratio of the unskilled wage to GDP per capita, which we have not yet explored, and which are available for seven Latin American regions between 1870 and 1940 .

Table 8 reports trends in the ratio of the unskilled worker's wage (w) to the returns on all factors per person as measured by Maddison's (1995) and Astorga and FitzGerald's (1998) estimates of GDP per capita (y). True, the ratio could be influenced by changes in the labor participation rate alone. If there was a sharp increase in population from, say, a rise in fertility and thus no increase in workers of adult age, w/y would (spuriously) rise. That is, nothing would happen to the wage or to GDP, but GDP per capita would fall. In contrast, if there was a sharp increase in population from the immigration of adult labor, w/y would fall, since the adult immigrants would tend to lower wages but increase per capita income as labor participation rates rose. Thus, the pre-WWI immigration into the Southern Cone and Cuba — where immigration rates were big - probably tends to make falling w/y trends overstate rising inequality there. Still, trends in w/y should approximate changes in the economic distance between the working poor near the bottom of the distribution and the average citizen in the middle of the distribution ${ }^{10}$.

Table 8 shows that any successful explanation of inequality changes in Latin America between 1870 and 1940 will have to be complex: the Heckscher-Ohlin trade model and the Lewis labor surplus model will not, by themselves, account for all the variety. Argentina, Mexico and Uruguay document the longest time series, and Table 8 shows that they share the same trends. They all underwent a long, steep decline in w/y before it flattened out or even rose after World War I. The turning point for all three is 1915-1919, a result consistent with wage-rental ratio trends in Table 7 documented for Argentina and Uruguay. Although its time series is shorter, Cuba seemed to obey the same laws of motion and the same turning point. Colombia's time series is even shorter than Cuba's, so we do not know whether 1910-1914 was a turning point for Colombia or not. The only evidence in Table 8 inconsistent with either the Hecks-

${ }^{10}$ It turns out that this statistic is highly correlated with more comprehensive inequality measures in the few cases where both are available in the Atlantic economy. See Williamson (1998d, Table 5). 
TABLE 8

Wage/GDP Per Capita Ratio Trends, 1870-1939

$$
(1913=1.00)
$$

\begin{tabular}{cccccccc}
\hline Period & Argentina & $\begin{array}{c}\text { Brazil, } \\
\text { Soutbeast }\end{array}$ & $\begin{array}{c}\text { Brazil, } \\
\text { Northeast }\end{array}$ & Colombia & Cuba & Mexico & Uruguay \\
\hline $1870-1874 \ldots \ldots \ldots$. & 1.6947 & & & & & & \\
$1875-1879 \ldots \ldots \ldots$. & 1.3286 & & & & & & \\
$1880-1884 \ldots \ldots \ldots$. & 1.4769 & & & & & 1.1881 & 1.9047 \\
$1885-1889 \ldots \ldots \ldots$. & 1.5663 & & & & & 1.0899 & 2.2004 \\
$1890-1894 \ldots \ldots \ldots$. & 1.5191 & & & & & 1.0387 & 2.2555 \\
$1895-1899 \ldots \ldots \ldots$. & 1.4428 & & & & & 1.0503 & 1.6946 \\
$1900-1904 \ldots \ldots \ldots$. & 1.4570 & 1.2209 & 1.5325 & & & 0.9702 & 1.3658 \\
$1905-1909 \ldots \ldots \ldots$. & 1.0500 & 1.1529 & 1.4431 & & 1.2108 & 0.8633 & 1.0966 \\
$1910-1914 \ldots \ldots \ldots$. & 1.0433 & 1.0318 & 1.1451 & 1.3317 & 0.9924 & 0.7738 & 1.0759 \\
$1915-1919 \ldots \ldots \ldots$. & 0.9230 & 0.7899 & 0.6751 & 1.5811 & 0.9329 & 0.2982 & 0.8981 \\
$1920-1924 \ldots \ldots \ldots$. & 1.1298 & 0.6280 & 0.5383 & 1.9191 & 1.2210 & 0.3615 & 1.1346 \\
$1925-1929 \ldots \ldots \ldots$. & 1.2440 & 0.5912 & 0.5361 & 2.2206 & 1.4785 & 0.4613 & 1.1785 \\
$1930-1934 \ldots \ldots \ldots$. & 1.4144 & 0.5760 & 0.3652 & 3.0818 & 1.5704 & 0.6903 & 1.4745 \\
$1935-1939 \ldots \ldots \ldots$. & 1.3032 & & & 2.0995 & 1.4853 & 0.5129 & 1.2918 \\
\hline
\end{tabular}

SOURCES: GDP per capita data for Argentina, Colombia, and Mexico are from Maddison (1995), while the information for Cuba is from Astorga and FitzGerald (1998). Income per capita estimates for the regions of Brazil are from Gomes (1986). Note that even though the PPP-adjustment benchmarks were based only on Astorga and FitzGerald, we have used the Maddison source of GDP per capita data here as it extends coverage for more years. (Astorga and FitzGerald offer only decadal coverage.) These GDP per capita figures were interpolated where necessary and rebased so that $1913=100$. The real wage data are from Williamson (1998c), Appendix Tables 1-6.

cher-Ohlin or the Lewis explanations is Brazil, which underwent a steady decline in w/y from the turn of the century onwards. The behavior of this inequality proxy can be best summarized for all of Latin America by pooling the annual data underlying the five-year averages in Table 8 . The results of a non-linear regression are plotted in Figure $11^{11}$, and the predicted time when w/y reached a minimum is 1918-1919.

"The ratio $\mathrm{w} / \mathrm{y}$ is regressed on time (coef $=-1.355, \mathrm{t}$-stat $=3.955$ ) and time-squared (coef $=+0.0004, t$-stat $=3.934)$, and the predicted minimum is 1918.8 . November 11 , the day of the official German surrender, was pretty close to 80 percent of the way through 1918. 


\section{FIGURE 11}

Trends in the Inequality Proxy (w/y) in Latin America: 1870-1940

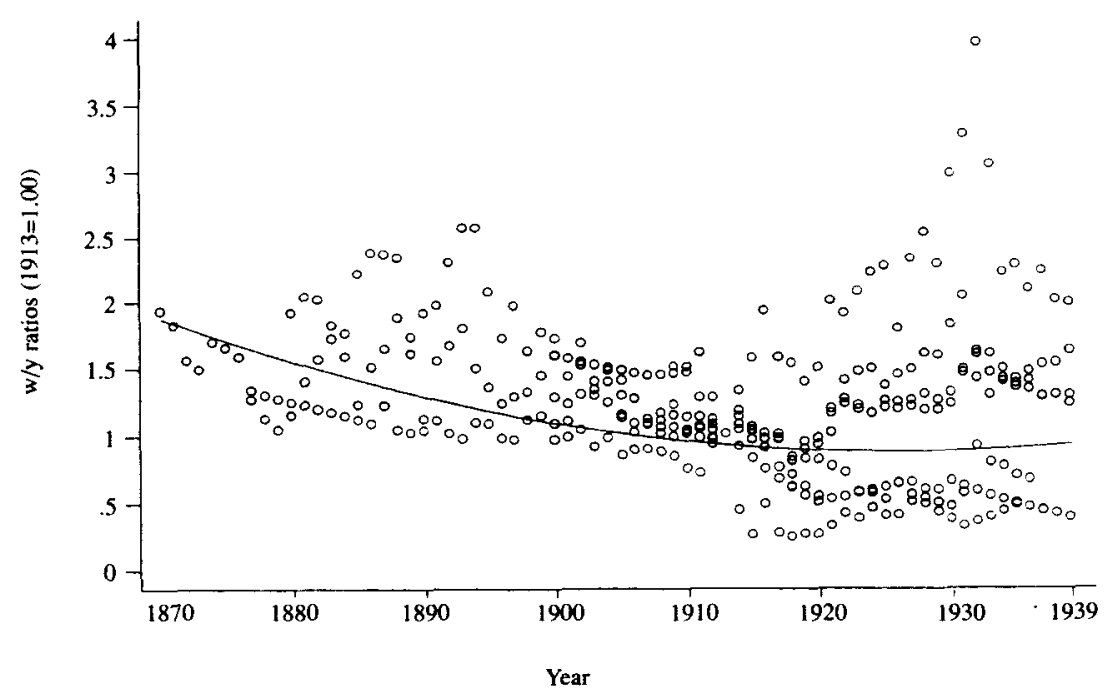

Why did the real wage lag behind GDP per capita in so much of Latin America during the first great globalization boom? Is this evidence of some weaker version of the Lewis model, one without a constant real wage but with sluggish real wage growth and modest trickling down? Is it evidence supporting the factor-price convergence theorem? Or is it both? And why the common turning point for economies with such different attributes? Since it seems unlikely that such dissimilar economies could share the same Lewis labor supply turning point (unless immigration was doing all the work), perhaps a more likely explanation lies with world markets. These countries were more likely to have shared similar price shocks which produced the same trends in $w / y$.

We have found an important Latin American stylized fact. Real wages lagged behind GDP per capita growth everywhere in Latin America up to the World War I decade. Real wages outstripped GDP per capita growth everywhere in Latin America thereafter. We interpret these trends as a proxy for rising inequality during the first great globalization boom and falling inequality during the interwar years. What accounts for this stylized fact? This paper will duck this question, adding it to that lengthening agen- 


\section{TABLE 9}

Regional Real Wage Indices for Brazil, 1855-1935

(SE-Southeast; NE-Northeast)

\begin{tabular}{|c|c|}
\hline Period & Average of (SE-NE)/NE ratio \\
\hline $1855-1859 \ldots$ & 2.89 \\
\hline $1860-1864 \ldots \ldots \ldots \ldots \ldots \ldots$ & 1.57 \\
\hline $1865-1869 \ldots \ldots \ldots \ldots \ldots . . . . . . . .$. & 1.35 \\
\hline $1870-1874 \ldots \ldots \ldots \ldots \ldots \ldots . . . . . . . .$. & 1.80 \\
\hline $1875-1879 \ldots \ldots \ldots \ldots \ldots . . . . . . . .$. & 2.51 \\
\hline 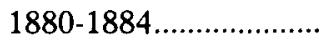 & 3.28 \\
\hline $1885-1889 \ldots \ldots \ldots \ldots \ldots \ldots$ & 4.33 \\
\hline 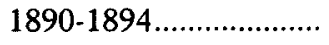 & 3.92 \\
\hline 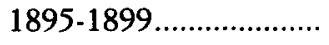 & 3.64 \\
\hline $1900-1904 \ldots \ldots \ldots \ldots \ldots \ldots$ & 2.65 \\
\hline 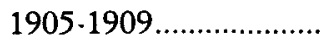 & 2.13 \\
\hline 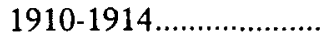 & 2.19 \\
\hline 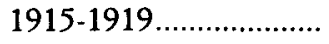 & 2.61 \\
\hline $1920-1924 \ldots \ldots \ldots \ldots \ldots . .$. & 2.92 \\
\hline $1925-1929 \ldots \ldots \ldots \ldots \ldots$ & 3.64 \\
\hline $1930-1935 \ldots \ldots \ldots \ldots \ldots \ldots$ & 6.03 \\
\hline
\end{tabular}

SOURCES AND NOTES: The real wage series used for the calculations were PPP-adjusted. See Williamson (1998c), Appendix Table 7.2.

$\mathrm{da}$, but it should be noted that the same stylized fact appears in Asia (Williamson 1998a, 1999a forthcoming) and the eastern Mediterranean (Williamson 1998b, 1999b forthcoming).

\section{AN AGENDA}

This real wage data base has served us well in generating a research agenda for the economic performance of Latin America over the century before 1940. By focusing on relative growth performance within Latin America, rather than between Latin America and the European OECD or the United States, two stylized facts have emerged that need explanations. Across the 20th century, Latin America has undergone dramatic convergence: living standards in poor countries have been catching up with those 
in rich. How much of this has been due to economic failure among the rich, and how much to economic success among the poor? And why did all of the convergence take place in two discrete steps, 1910-1930 and 1970-1990? Do these two periods have enough in common to offer a common explanation for both? The 19th century was different: living standard gaps between rich and poor parts of Latin America widened up to the 1890 s, while they narrowed thereafter. What accounts for the inverted-U?

Any effort to confront these two stylized facts must augment the quality and coverage of those explanatory variables which have had success more generally in the new growth literature. In particular, any agenda whose goal it is to isolate the role of policy in accounting for these trends, needs to control for demography, the luck of the draw in world commodity markets, the breakdown of the tyranny of distance, the rise and fall of integrated world factor markets, and other forces.

Trends in the wage-rental ratio and in the wage/GDP-per-capita ratio have produced a third stylized fact. Both of these ratios trend steeply downwards to World War I, then trend upwards immediately thereafter. Why? Since both of these measures are proxies for inequality, they take on even greater importance. So, what accounts for this stylized fact, a fact that has been recently discovered in Asia and the Mediterranean too? Is it the consequence of the Heckscher-Ohlin model? If so, is it price shocks doing the work? Or, is it instead changes in attitudes towards globalization, open prior to World War I and closed thereafter? If it is price shocks, how much of it is attributable to the fundamentals underlying «world» terms of trade changes, and how much to changing transport costs and policy? Alternatively, was factor accumulation doing the work, heavy immigration of capital and labor combining with less elastic land supplies prior to World War I, while the opposite thereafter? In short, was it commodity markets or factor markets which accounted for that inequality turning point? Or was it something else?

\section{ENDNOTE}

I would like to thank Fausto Alzati, Luis Bértola, Luis Catao, John Coatsworth, Sebastian Coll, Roberto Cortés-Conde, Gerry della Paolera, Aurora Gómez, Steve Haber, Robert Levine, Carlos Newland and Jaime Reis for their help in guiding me to and sometimes through the data underlying the analysis in this paper. I would also like to acknowledge the excellent 
research assistance of Davin Chor, Ximena Clark, Graciela Márquez, Rebecca Rissman and Matt Weinzierl, all of whom have been involved at various points since 1995 when this project started. The prices, wages and rent data underlying this paper can be found in «Real Wages and Relative Factor Prices in the Third World: Latin America», HIER Discussion Paper 1853, Department of Economics, Harvard University (November 1998), referred to in the text as Williamson (1998c). This paper can also be found at my website under www.economics.harvard. However, that data base is being revised extensively (spring 1999) and the revisions can be obtained by contacting the author at his email address jwilliam@kuznets.fas.harvard.edu. Williamson (1998c) has two HIER Discussion Paper companions: «Real Wages and Relative Factor Prices in the Third World 1820-1940: Asia» [1998a] and «Real Wages and Relative Factor Prices in the Third World 1820-1940: The Mediterranean Basin» [1998b] which are also available upon request. The data from Asia and the Mediterranean, and the two papers themselves, can also be downloaded from my web site, but the underlying data is also being revised and augmented extensively (spring 1999).

\section{REFERENCES}

Allen, R. (1998), «The Great Divergence: Wages and Prices from the Middle Ages to the First World War», paper presented to the Conference on Regions, Queens University, Kingston, Canada (March 6-7).

Astorga, P., and FrrzGerald, V. (1998), «The Standard of Living in Latin America During the Twentieth Century», Development Studies Working Paper n. ${ }^{\circ} 117$, Queen Elizabeth House, St. Antony's College, University of Oxford (May). Bairoch, P. (1975), The Economic Development of the Third World since 1900 (London: Methuen).

Bertola, L.; Calicchio, L.; Camou, M., and Porcile, G. (1999), «Southern Cone Real Wages Compared: A Purchasing Power Parity Approach to Convergence and Divergence Trends, 1870-1996», Documento de Trabajo \#44, Unidad Multidisciplinaria, Facultad de Ciencias Sociales.

Blainey, G. (1966), The Tyranny of Distance: How Distance Shaped Australia's History (Melbourne: Macmillan, revised $1982 \mathrm{ed}$.).

Bloom, D., and Williamson, J. G. (1998), «Demographic Transitions and Economic Miracles in Emerging Asia», World Bank Economic Review 12 (September), pp. 419-455.

BrADING, C. W. (1969), «Un análisis comparativo del costo de la vida en diversas capitales de hispanoamérica», Boletín Histórico de la Fundación John Boulton 20 (Marzo), pp. 229-63. 
Bulmer-Thomas, V. (1994), The Economic History of Latin America Since Independence (Cambridge: Cambridge University Press).

COATSWORTH, J. (1981), Growth Against Development - The Economic Impact of Railroads in Porfirian Mexico (Dekalb, Ill.: Northern Illinois University Press).

- (1993), «Notes on the Comparative Economic History of Latin America and the United States», in W. L. Bernecker and H. W. Tobler (eds.), Development and Underdevelopment in America: Contrasts of Economic Growth in North and Latin America in Historical Perspective (New York).

Diakosavvas, D., and Scandizzo, G., «Trends in the Terms of Trade of Primary Commodities, 1900-1982: The Controversy and Its Origins», Economic Development and Cultural Change 39 (January), pp. 231-264.

Diaz-Alejandro, C. F. (1970), Essays on the Economic History of the Argentine Republic (New Haven, Conn.: Yale University Press).

EllsworTH, P. T. (1956), «The Terms of Trade between Primary Producing and Industrial Countries», Inter-American Economic Affairs 10 (Summer), pp. 47-65.

ENGERMAN, S. L., and SoKOlOFF, K. L. (1996), «Factor Endowments, Institutions, and Differential Paths of Growth Among New World Economies: A View from Economic Historians of the United States», in S. Haber (ed.), How Latin America Fell Bebind (Stanford, Cal.: Stanford University Press).

FERENCZI, I., and WillCOX, W. F. (1929), International Migrations, vol. I (New York: National Bureau of Economics Research).

FLETChER, M. E. (1958), «The Suez Canal and World Shipping, 1869-1914», Journal of Economic History 18 (December), pp. 556-73.

Gerschenkron, A. (1952), «Economic Backwardness in Historical Perspective», in B. Hoselitz (ed.), The Progress of Underdeveloped Areas (Chicago: University of Chicago Press).

Gomes, G. M. (1986), The Roots of State Intervention in the Brazilian Economy (New York: Praeger).

Harley, C. K. (1980), «Transportation, the World Wheat Trade, and the Kuznets Cycle, 1850-1913», Explorations in Economic History 17 (July), pp. 218-50.

- (1988), «Ocean Freight Rates and Productivity, 1740-1913: The Primacy of Mechanical Invention Reaffirmed», Joumal of Economic History 48 (December), pp. 851-76.

Hatton, T. J., and Williamson, J. G. (1994), «Late-Comers to Mass Emigration: The Latin Experience», in T. J. Hatton and J. G. Williamson (eds.), Migration and the International Labor Market, 1850-1939 (London: Routledge).

- (1998), The Age of Mass Migration: Causes and Economic Impact (New York: Oxford University Press).

KRUGMAN, P. (1991a), Geograpby and Trade (Cambridge, Mass.: MIT Press).

- (1991b), «Increasing Returns and Economic Geography», Journal of Political Economy 99 (June), pp. 483-99.

Krugman, P. R., and Venables, A. (1990), «Integration and the Competitiveness of Peripheral Industry», in Bliss, C. and J. Braga de Macedo (eds.), Unity with Diversity in the European Community (Cambridge: Cambridge University Press), pp. 56-77.

- (1995), «Globalization and the Inequality of Nations», NBER Working Paper 5098, National Bureau of Economic Research, Cambridge, Mass. (April). 
LEFF, N. H. (1972), «Economic Development and Regional Inequality: Origins of the Brazilian Case», Quarterly Journal of Economics 86 (May), pp. 243-62.

- (1992), «Economic Development in Brazil, 1822-1913», First Boston Working Paper FB-92-02, Columbia University.

LEwIS, W. A. (1954), «Economic Development with Unlimited Supplies of Labour», Manchester School of Economic and Social Studies 22 (May), pp. 139-91.

- (1969), Aspects of Tropical Development (Uppsala: Wiksell).

- (1978a), The Evolution of the International Economic Order (Princeton, N.J.: Princeton University Press).

- (1978b), Growth and Fluctuations 1870-1913 (Cambridge: Allen and Unwin).

Maddison, A. (1991), Dynamic Forces in Capitalist Development (Oxford: Oxford University Press).

- (1995), Monitoring the World Economy 1820-1992 (Paris: OECD Development Centre Studies).

MoKYR, J. (1990), The Lever of Riches: Technological Creativity and Economic Progress (New York: Oxford University Press).

MoredA, V. P. (1987), «Spain's Demographic Modernization, 1800-1930», in N. Sanchez-Albornoz (ed.), The Economic Modemization of Spain, 1830-1930 (New York: New York University Press).

Newland, C. (1998), «Economic Development and Population Change: Argentina 1810-1870», in J. Coatsworth and A. Taylor (eds.), Latin America and the World Economy Since 1800 (Cambridge, Mass.: Harvard University Press).

NorTH, D. C. (1958), «Ocean Freight Rates and Economic Development 1750-1913», Journal of Economic History 18 (December), pp. 538-55.

O'Rourke, K. H. (1997), «The European Grain Invasion, 1870-1913», Joumal of Economic History 57 (December), pp. 775-801.

O'Rourke, K. H.; Taylor, A. M., and Williamson, J. G. (1996), «Factor Price Convergence in the Late 19th Century», International Economic Review 37 (August), pp. 499-530.

O'Rourke, K. H., and Williamson, J. G. (1994), «Late 19th Century Anglo-A. merican Factor Price Convergence: Were Heckscher and Ohlin Right?» Journal of Economic History 54 (December), pp. 892-916.

- (1997), «Around the European Periphery 1870-1913: Globalization, Schooling and Growth», European Review of Economic History 1 (August), pp. 153-90.

- (1999), Globalization and History (Cambridge, Mass.: MIT Press).

PARThASARATHI, P. (1998), «Rethinking Wages and Competitiveness in the Eighteenth Century: Britain and South India», Past and Present 158 (February), pp. 79-109.

Pomeranz, K. (1997), «Rethinking $18^{\text {th }}$ Century China: A High Standard of Living and Its Implications», paper presented to the All-UC Group in Economic History Conference on Rethinking the History of Wages, Prices and Living Standards, Davis, California (November 14-16).

Radalet, S.; Sachs, J., and Lee, J.-W. (1997), «Economic Growth in Asia», Chap. 2 in Emerging Asia (Manila: Asian Development Bank). 
SACHS, J. D., and WARNER, A. (1995), «Natural Resource Abundance and Economic Growth», NBER Working Paper, n. ${ }^{\circ}$ 5398, National Bureau of Economic Research, Cambridge, Mass. (December).

SánCheZ-AlboRNOZ, N. (1974), trans. by W. Richardson, The Population of Latin America: A History (Berkeley, California: University of California Press).

SÁnChez-Alonso, B. (1998), «What Slowed Down the Mass Migration from Spain in the Late Nineteenth Century?», paper presented to the Conference on Long Run Economic Change in the Mediterranean Basin, Istanbul, Turkey (June 4-7).

- (1999 forthcoming), «What Slowed Down the Mass Emigration from Spain Before WWI? A Comparison with Italy», Chap. 11 in S. Pamuk and J. G. Williamson (eds.), Economic Cbange in the Mediterranean Before 1950 (London: Routledge, forthcoming).

Taylor, A. M. (1992), Argentine Economic Growth in Comparative Perspective, Ph. D. thesis, Department of Economics, Harvard University.

- (1994), «Mass Migration to Distant Southern Shores», in T. J. Hatton and J. G. Williamson (eds.), Migration and the International Labor Market, 1850-1939 (London: Routledge).

TAYlor, A. M., and WLliamson, J. G. (1997), «Convergence in the Age of Mass Migration», European Review of Economic History 1 (April), pp. 27-63.

Timmer, A. S., and Williamson, J. G. (1998), «Immigration Policy Prior to the Thirties: Labor Markets, Policy Interactions and Globalization Backlash», Population and Development Review 24 (December), pp. 737-771.

Williamson, J. G. (1965), «Regional Inequality and the Process of National Development», Economic Development and Cultural Change 13, 4, pt. II (July), Supplement.

- (1995), «The Evolution of Global Labor Markets Since 1830: Background Evidence and Hypotheses», Explorations in Economic History 32 (April), pp. 141-96.

- (1996), «Globalization, Convergence and History», Journal of Economic History 56 (June), pp. 277-306.

- (1997), «Globalization and Inequality, Past and Present», World Bank Research Observer 12 (August), pp. 117-35.

- (1998a), «Real Wages and Relative Factor Prices in the Third World 1820-1940: Asia», HIER Discussion Paper 1844, Department of Economics, Harvard University (August).

- (1998b), «Real Wages and Relative Factor Prices in the Third World 1820-1940: The Mediterranean Basin», HIER Discussion Paper 1842, Department of Economics, Harvard University (July).

- (1998c), «Real Wages and Relative Factor Prices in the Third World 1820-1940: Latin America», HIER Discussion Paper 1853, Department of Economics, Harvard University (November).

- (1998d), «Growth, Distribution and Demography: Some Lessons from History», Explorations in Economic History 35 (July), pp. 241-71.

- (1999a forthcoming), «Real Wages, Inequality and Globalization in Asia Before 1840», in A. J. H. Latham (ed.), Asia Pacific Dynamism 1500-2000 (London: Routledge, forthcoming). 
- (1999b forthcoming), «Real Wages and Relative Factor Prices Around the Mediterranean 1500-1940», Chp. 3 in S. Pamuk and J. G. Williamson (eds.), Economic Change in the Mediterranean Before 1950 (London: Routledge, forthcoming).

WoOD, A. (1994), North-South Trade, Employment and Inequality: Changing Fortunes in a Skill-Driven World (Oxford: Clarendon Press). 